Article

\title{
Towards a Rural Revitalization Strategy for the Courtyard Layout of Vernacular Dwellings Based on Regional Adaptability and Outdoor Thermal Performance in the Gully Regions of the Loess Plateau, China
}

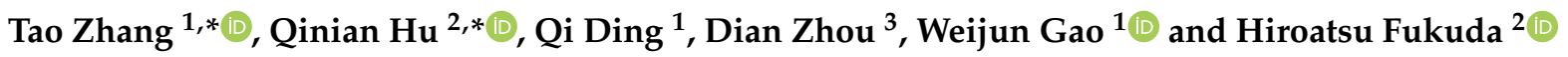 \\ 1 Innovation Institute for Sustainable Maritime Architecture Research and Technology, \\ Qingdao University of Technology, Qingdao 266033, China; ding950813@163.com (Q.D.); \\ gaoweijun@me.com (W.G.) \\ 2 Faculty of Environmental Engineering, The University of Kitakyushu, Kitakyushu 808-0135, Japan; \\ fukuda@kitakyu-u.ac.jp \\ 3 School of Human Settlements and Civil Engineering, Xi'an Jiaotong University, Xi'an 710049, China; \\ Dian-z@mail.xjtu.edu.cn \\ * Correspondence: zhangtao841120@163.com (T.Z.); tracynian@163.com (Q.H.)
}

Citation: Zhang, T.; Hu, Q.; Ding, Q.; Zhou, D.; Gao, W.; Fukuda, H.

Towards a Rural Revitalization Strategy for the Courtyard Layout of Vernacular Dwellings Based on Regional Adaptability and Outdoor Thermal Performance in the Gully Regions of the Loess Plateau, China. Sustainability 2021, 13, 13074. https:/ / doi.org/10.3390/su132313074

Academic Editors: Nikos

A. Salingaros, Alexandros A. Lavdas, Michael W. Mehaffy and Ann Sussman

Received: 9 October 2021

Accepted: 16 November 2021

Published: 25 November 2021

Publisher's Note: MDPI stays neutral with regard to jurisdictional claims in published maps and institutional affiliations.

Copyright: (c) 2021 by the authors. Licensee MDPI, Basel, Switzerland. This article is an open access article distributed under the terms and conditions of the Creative Commons Attribution (CC BY) license (https:// creativecommons.org/licenses/by/ $4.0 /)$.

\begin{abstract}
In the context of the Chinese rural revitalization strategy, the unique residential characteristics of local vernacular dwellings formed by profound historical and cultural accumulation, climate characteristics, and residential lifestyle have undergone profound change in the gully regions of the Loess Plateau. Accordingly, the contradictions of traditional vernacular dwelling protection, increasing living requirements, and ecological protection have intensified. In this paper, with the aim of optimizing courtyard layout for vernacular dwellings, the thermal performance and regional adaptability of different courtyard layouts were analyzed using Ladybug and Honeybee tools. According to the thermal simulation within the courtyard, the current optimal layout type was determined, and then, several ecological optimization designs were proposed for the further improvement of it. The results revealed that the improved vernacular dwelling model has better regional adaptability, which corresponds to the local living culture and living habits, saves land resources, and provides a better thermal comfort performance. This research not only has a positive function for the protection of local architectural culture, but also plays an essential role in improving residents' living comfort and living standards. We hope that the research results are meaningful and can be used as a reference for future rural construction in the Loess Plateau.
\end{abstract}

Keywords: regional adaptability; vernacular dwelling; outdoor thermal performance; ecological spatial layout; rural habitat; gully regions of the Loess Plateau

\section{Introduction \\ 1.1. Regional Background}

The Loess Plateau is located in the central west of China, which is one of the earliest human settlements and most fragile ecological areas, covered with $30 \mathrm{~m}$-300 m-thick calcareous yellow soil [1]. It is about 530 thousand square kilometers, accounting for $1 / 18$ of the total Chinese territory [2]. The gully region is a subtype region and natural geographical unit of the Loess Plateau, which mainly refers to the Wei Bei Loess Plateau, the Shan Bei Loess Plateau, and the Long Dong Loess Plateau, including 7 cities, 18 counties, a population of about 44.9 million, and a total area of about 14.8 thousand square kilometers (Figure 1, Table 1) [3]. 


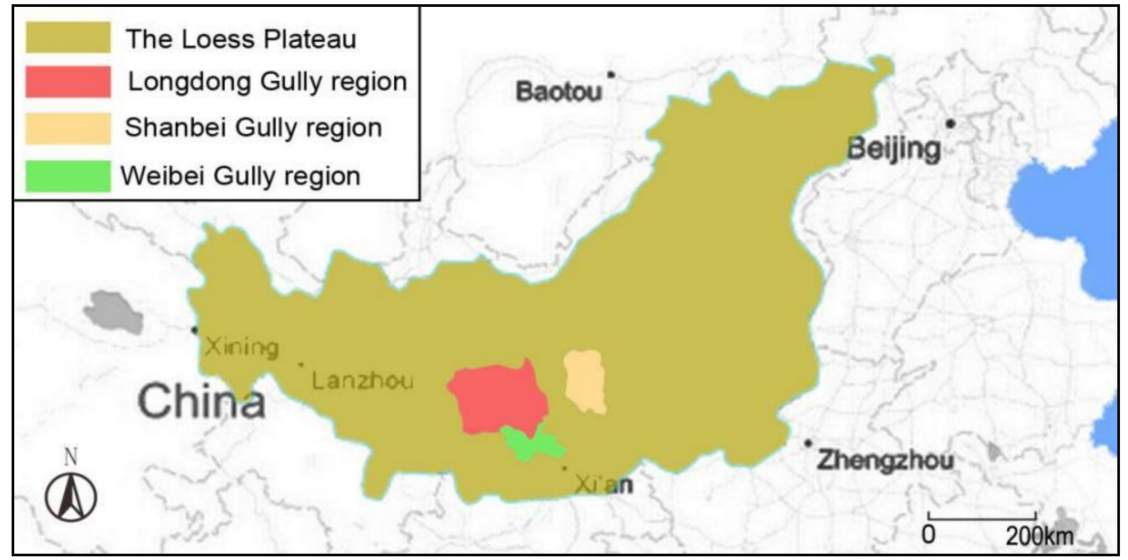

Figure 1. Location of gully regions.

Table 1. Space distribution in gully regions of the Loess Plateau.

\begin{tabular}{|c|c|c|c|c|c|}
\hline Region & Sub-Regions & Provinces & Cities & Land Areas $\left(\mathrm{km}^{2}\right)$ & $\begin{array}{l}\text { Total Population } \\
\text { (mil.) }\end{array}$ \\
\hline \multirow{7}{*}{$\begin{array}{l}\text { Gully regions of } \\
\text { Loess Plateau }\end{array}$} & \multirow{2}{*}{ Gully region of Long Dong } & \multirow{2}{*}{ Gan Su } & Qing Yang & \multirow{2}{*}{9213} & \multirow{7}{*}{44.9} \\
\hline & & & Ping Lang & & \\
\hline & \multirow{3}{*}{ Gully region of Shan Bei } & \multirow{3}{*}{ Shaanxi } & Yan'an & \multirow{3}{*}{3505} & \\
\hline & & & Tong Chuan & & \\
\hline & & & Wei Nan & & \\
\hline & \multirow{2}{*}{ Gully region of Wei Bei } & \multirow{2}{*}{ Shaanxi } & Xian Yang & \multirow{2}{*}{2058} & \\
\hline & & & Bao Ji & & \\
\hline
\end{tabular}

Compared with other regions in the Loess Plateau, although it is full of gullies with significant soil erosion, the broad tableland area is very suitable for farming, and it has the highest population density area in the whole of the Loess Plateau. Additionally, although gully regions belong to the cold region in China according to the thermal design code for civil building (GB 50176-2016) [4] and a cold semi-arid climate according to the Köppen climate classification system, the summer temperature is also very high, and average relative humidity in the gully regions is about $45 \%$ the winter and $65 \%$ in summer [5]. Figure 2 shows the annual hourly temperature and mean monthly temperature of the typical cities in the gully regions [5].

Vernacular dwelling is a term used to categorize methods of construction that use locally available resources to address local needs [6]. Vernacular dwelling results from long-term growth and is part of traditional popular culture; therefore, it is considered well adapted to the natural and social conditions of a specific location [7].

Since the construction of the new socialist countryside carried out in 2005, residential settlements in China have entered a period of drastic transformation. Natural resources have been significantly degraded due to the increased urban populations, settlement sprawl, the development of transportation networks, and industrial activities [8]. Due to the improvement of traffic and information conditions, modern rural buildings and residential patterns in developed regions have gradually replaced the traditional dwellings in various ways [9]. This also has profound impacts on the vernacular dwellings in the gully regions of the Loess Plateau. 


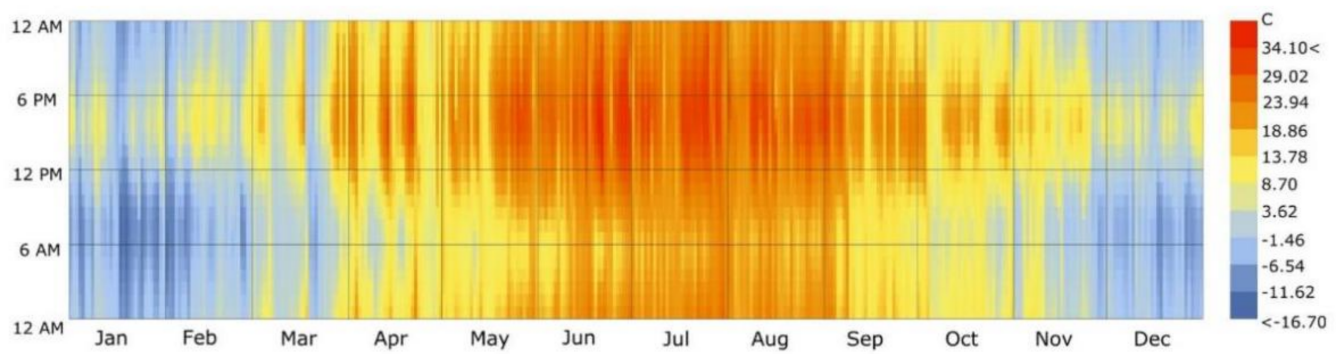

(a)

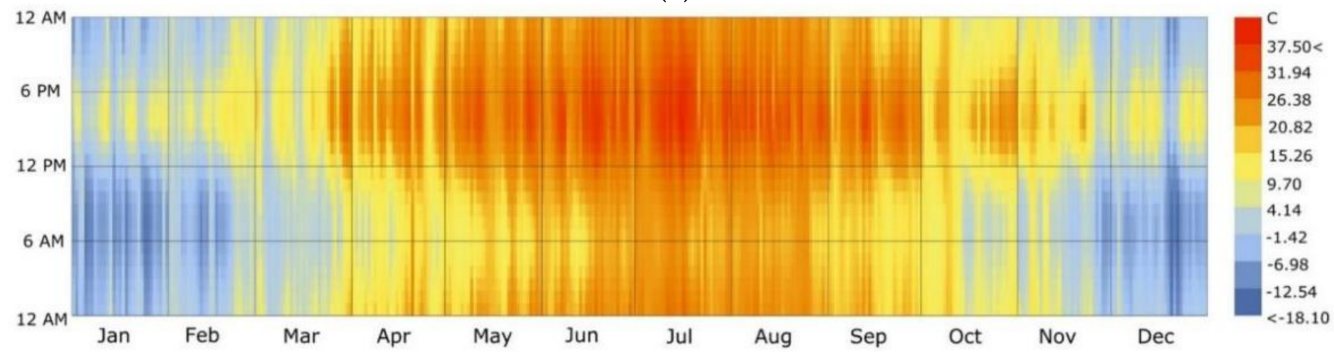

(b)

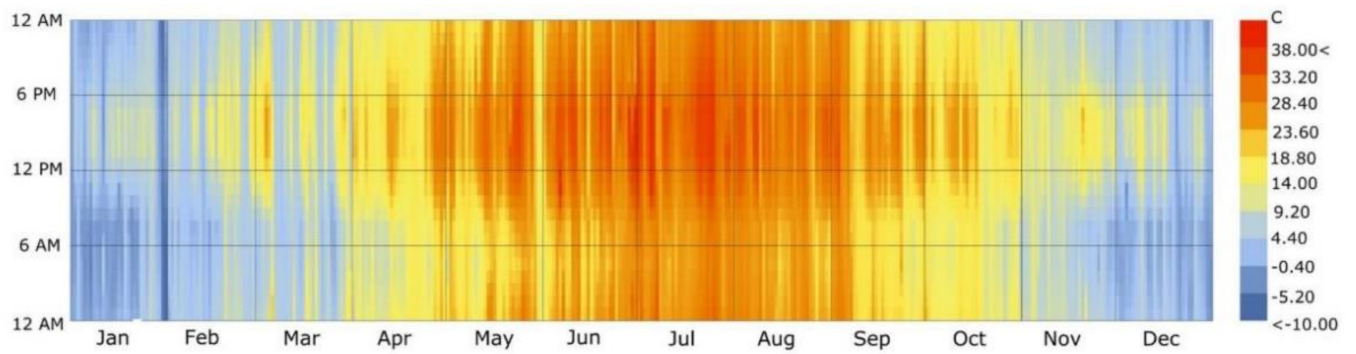

(c)

Figure 2. Annual hourly temperature of the typical cities in each gully region. (a) Ping Lang (Gully region of Long Dong). (b) Yan'an (Gully region of Shan Bei). (c) Bao Ji (Gully regions of Wei Bei).

\subsection{The Main Problems of Spatial Layout in the Construction of Newly Built Vernacular Dwellings}

1.2.1. Replacement and Gradual Disappearance of the Regional Residential System

Throughout history, in order to adapt to the arid climate and make the best use of limited natural resources, traditional vernacular dwellings have been characterized by low cost, low energy consumption, and low pollution regarding the environmental impact on nature in the whole life cycle. These dwellings also adapt local culture and residential living habits, and climate-adaptable designs and layout make them merge harmoniously with nature. Currently, this regional adaptability is changing with the development of social productivity, modern transportation, and the improvement of construction; the architectural culture in developed areas shows a deep influence on vernacular dwellings in the gully regions.

Nowadays, without scientific designs and planning, most of the newly built dwellings in the gully regions ignore the relationship between dwellings and the surrounding environment. The style of new vernacular buildings emphasizes the unity of the village's facial feature, leading to excessively monotonous and rigid architectural forms, and some of courtyard layouts are unreasonable, as shown in Figure 3. Meanwhile, space division mainly copies that of modern houses in other areas without consideration of the local environment or living habits. The gap between design and reality often occurs in local residential areas in the process of new countryside construction [10]. 


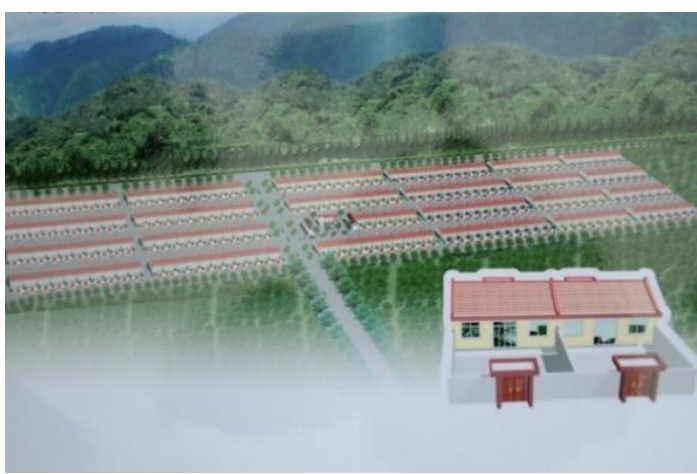

(a)

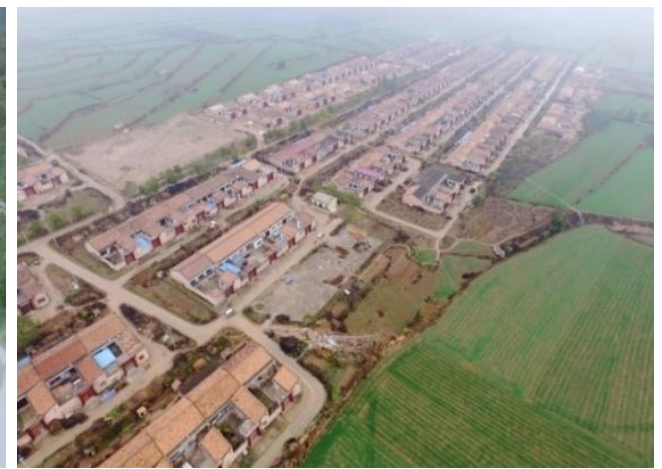

(b)

Figure 3. Annual hourly temperature of the typical cities in each gully region. (a) Monotonous and rigid architectural planning of Gun village. (b) Monotonous and rigid vernacular buildings under construction in Gun village.

\subsubsection{Poor Outdoor Thermal Environment in Courtyards}

With the development of modern meteorology, Landsbur noted that the temperature and humidity of the area near edge land are influenced by vegetation, soil, and landscape; this is actually a kind of microclimate research, i.e., the land microclimate [11]. Courtyard space in vernacular dwellings is within the scope of microclimate research; the courtyard should have the functions of adjusting the thermal environment, preventing wind and sand, and creating a comfortable living environment. For residents, the courtyard is an important productive and living space, and a comfortable thermal environment has a huge influence on people's living quality. Few studies have been conducted on outdoor thermal comfort in the Loess Plateau. However, along with the rural revitalization in recent years, the problem of a poor outdoor thermal environment in courtyards has gained researchers' attention. Because of the poor thermal environment in courtyards, the thermal environment can be improved by planting in the Loess Plateau [12]. According to our field measurements, we found that courtyards in the gully regions do not act as an adjusting space for the thermal environment.

\subsubsection{Functional Disorder of Courtyard Layouts in Vernacular Dwellings}

Courtyards in gully regions have functions for both productivity and living, as shown in Table 2. Inside the courtyard, there are lots of living activities, such as chatting, taking shade, washing and laundry, and so on. There are also some productivity-related activities, e.g., residents store their farming tools, park farming vehicles, store dry grains, or build rooms for livestock there.

Table 2. Functions and activities in courtyards.

\begin{tabular}{cc}
\hline Courtyard Functions & Contents \\
\hline & Relaxation \\
Living activities & Laundry \\
& Parties \\
\hline Productivity-related activities & Cultivation \\
& Drying grain \\
& Planting \\
& Vehicle parking \\
& Storing \\
\hline
\end{tabular}

Currently, the two functions of productivity and living are overlain without a reasonable design in most newly built vernacular dwellings, which causes inconvenience and disorder between the different functions, as shown in Figure 4. 


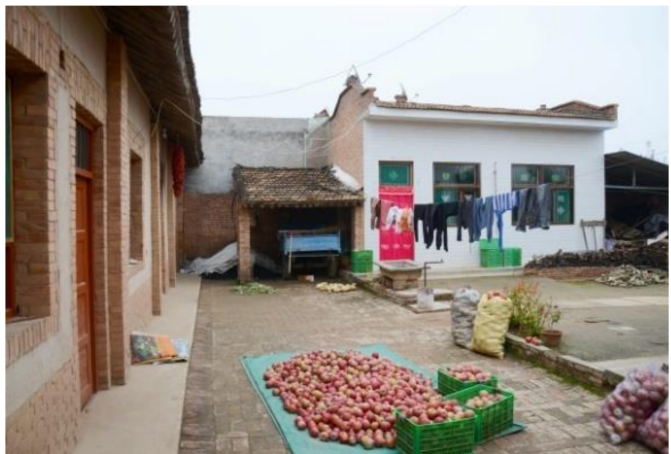

(a)

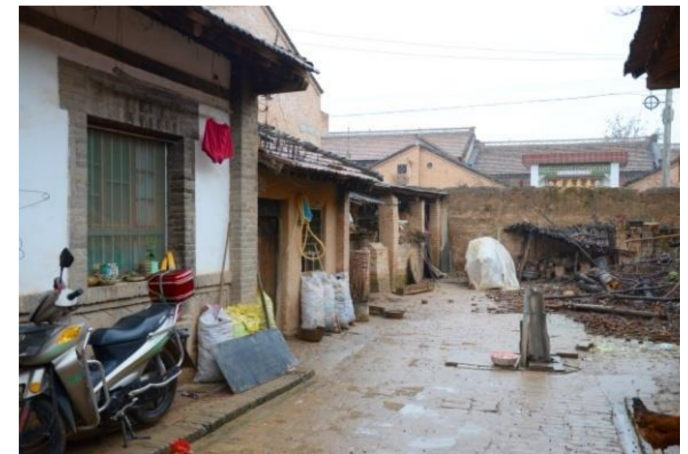

(b)

Figure 4. Courtyard layout in disorder. (a) Vernacular courtyard in Liang Jia Zhuang, Chun Hua County. (b) Vernacular courtyard in Yu Jia Gong, Yong Shou County.

According to these problems, this research hopes to propose a layout pattern that can adapt local climate and culture, ecological, energy saving and also has comfort thermal performance. Under the current new rural construction in gully regions, we hope that this paper will not only have a positive function on local architectural cultural protection but that it will also play an essential role in improving local living comfort.

\section{Literature Review}

\subsection{Research Status}

Much research has proved that traditional buildings usually possess better regional adaptability and are successful in achieving harmony between dwellings and the climatic environment. Hiroshi et al. researched four Japanese traditional farmhouses using both in situ measurements and computer simulations, and found that cooling technologies, such as solar shading by thatched roofs, earthen floors, and natural ventilation, are effective for interior cooling [13]. Manioğlu and Yllmaz studied energy-saving design strategies used in an ancient house in Mardin, Turkey [14]. They made a simplified thermal evaluation and comparison of a traditional house with a contemporary house by using an in situ measurement method and questionnaires. Their findings revealed that traditional houses performed better in thermal comfort and energy saving. Silvia Martin performed the measurement and analysis of the thermal environment of different dwellings built using different materials in Spain, and determined that the traditional construction material had a better thermal environment and living comfort [15].

In order to improve the thermal environment in traditional dwellings, courtyards, as a traditional and popular construction feature in China's urban buildings, have been researched by various methods and from many different aspects. The thermal performance of courtyards has been evaluated using computational fluid dynamics (CFD) software; using Parabolic Hyperbolic Or Elliptic Numerical Integration Code Series (PHOENICS) for wind environment simulations; and using the EnergyPlus-based software, DesignBuilder, for energy simulations [16]. The present study focuses on the impact of courtyard design factors (such as proportion, orientation, geometry, opening characteristics, and material) and its components (such as shading devices, vegetation, and water pool) on energy consumption, indoor and outdoor temperatures, solar radiation, and natural ventilation in different climates [17]. In order to improve courtyards' thermal performance, natural ventilation has been widely researched [18]; indoor and outdoor air temperature were studied via field measurements and computational fluid dynamics (CFD) models [19]; the residents of traditional dwellings have also been researched, especially regarding their thermal adaptive behaviors [20]. However, there is no research focusing on the thermal impacts of different courtyard layouts, nor is there any using the courtyard layout to classify the different thermal performance dwellings. Generally, research has adopted one typical traditional dwelling as a model and simulated its thermal performance combining 
various factors. However, for this study, we focused on space layout, which is the first step in courtyard design; this was then followed by studying the materials and fenestration.

The modernization of construction technology inherited from traditional buildings not only retains traditional contents but also problem-solving design ideas. Such kind of modernization does not rely on high-tech, energy-consuming equipment, but adopts ecological design methods to improve the form, space, layout, and structure of traditional dwellings. Jyptirmay Mathur researched the indoor thermal environment in Indian traditional dwellings and found that the indoor thermal environment and comfort can by adjusted and improved by the utilization of natural ventilation [21]. The Egyptian architect, Hassan Fathy, and Indian architect, Charles Correa, are two outstanding architects, both of whom researched local architecture and proposed improvements based on the improvement of local building technologies and materials [22]. Hassan Fathy mainly re-evaluated traditional technologies with the help of modern physics, human science, and related disciplines such as materials science and physiology, and then proposed design strategies to improve and update traditional technologies [23].

\subsection{Vernacular Dwelling Research in the Loess Plateau}

In western areas of China, Wang Yi researched the thermo-technical design of envelop exterior construction. Through the evaluation of indoor climates in residential dwellings in the Loess Plateau and an analysis of moisture condensation on exterior constructions, she submitted several principles for dwellings in the Loess Plateau [24]. Zhang Jiali took residential dwellings in Ying Bian County of the Loess Plateau as an example, and conducted field investigations on indoor and outdoor temperature and duration of sunshine. Combining the questionnaire and local climate and economic situation, Zhang carried out a comprehensive analysis on dwellings' construction, material, and thermal construction, and thus submitted several problems and proposals for improvements [25]. Liu Jia Ping, as a significant researcher in this field, researched cave dwellings in the Loess Plateau, residential dwellings in Guan Zhong Plain, and immature dwellings in northwest China [26], which form an important basis for this paper. His findings revealed the thermal mechanism of traditional vernacular dwellings and the energy performance of new Yaodong dwellings [27].

Combined with improved architectural techniques, the newly built dwellings should have a lower energy consumption and be more comfortable for living. Liu Jia Ping planned and designed buildings in Yin Chua Jian Fu Qiao village in a western area of China, which achieved the lower energy consumption by optimizing the layout, simplifying the construction, and the utilization of passive solar houses and biogas equipment [28]. "Green Architectural System And Habitat Patterns in Loess Plateau" by Zhou Ruo Qi, published in 2007, systematically established a research framework, and the research results are of significance for the modern reconstruction of traditional vernacular dwellings, the optimization of combined climatic adaptability and modern construction technologies, and living comfort improvements [29].

Sun $\mathrm{Na}$ carried out a field investigation and conducted a questionnaire survey on thermal comfort in the Loess Plateau using a simulation of energy consumption by DeSTh. She proposed and performed the simulation using the local abundant energy-solar energy to improve the indoor thermal environment and living comfort [30]. Yang Liu and Zhao Wen Xue performed research on the thermal environment of traditional vernacular dwellings in Guan Zhong of Shannxi Province. They proposed several methods to improve indoor thermal environment and living comfort by combining field investigations and software simulations [31,32].

At present, the research on traditional dwellings puts more attention on combining single buildings with the residential environment. The focus of research on traditional dwellings has also shifted from the form, space, and structure of a single unit to the application of ecological experience. The traditional dwellings on the Loess Plateau have been researched regarding the buildings' form, space materials, structural function, the 
formation of settlements, as well as related historical changes, ecological experience, and renovation. A relatively complete and systematic survey was carried out and a large amount of research materials were accumulated; theoretical results with certain practical value were also obtained, and attention has been paid to the perspectives of cultural science and climatology; the research content has thus been broadened and deepened. All of these aspects are very useful for exploring a kind of new urbanization construction that can achieve energy saving and can better inherit and develop the traditional dwellings on the Loess Plateau.

However, due to the late start of domestic research on traditional dwellings on the Loess Plateau, the present research mainly focuses on the indoor thermal environment and living comfort in the main buildings of vernacular dwellings without systematic research on the outdoor thermal environment. However, courtyards are an important part of the local vernacular dwellings, and they have significant functions for the indoor and outdoor thermal environment and living comfort.

\section{Material and Methods}

\subsection{Research Framework}

The gully regions of the Loess Plateau across several provinces, from the overall point of view, have a similar climate, social, and cultural background. However, due to the continuous dynamic process of the development and construction, influenced by local economy and culture of each area, the types and characteristics of residential houses are inextricably linked but have their own subtle differences. Based on the above literature review and the regional adaptability, this research is based on the historical context of residential development in the gully regions of the Loess Plateau, taking vernacular dwellings as the research object in order to understand and master the regional adaptability characteristics of traditional residential buildings and the real needs of residential use and to summarize the current residential design and construction system.

Combining the climatic characteristics and traditional cultural features of the gully regions of the Loess Plateau, this research explores and summarizes the low-carbon concept, ecological ideas and wisdom, and the proportional relationship between architectural volume and courtyard space contained within the spatial layout of traditional residential courtyards. Then, the regional adaptability characteristics of traditional houses are extracted and condensed, and the main types and characteristics of current residential development are classified and summarized. Furthermore, we used thermal environment simulation software to simulate, compare, and analyze the outdoor thermal environment of different spatial courtyard layouts. On this basis, using the summarized advantages of traditional residential courtyard spatial layouts and simulation results, optimal design principles for new vernacular dwellings are submitted and the courtyard layout of new residential buildings is optimized.

In order to perform the comparative analysis of the advantages and disadvantages of different types of courtyards, thermal comfort simulation software was adopted. Based on the simulated results and traditional spatial layout characteristics, optimal design principles for new vernacular dwellings are submitted, and these improvements were again verified by simulation software, as shown in Figure 5. 


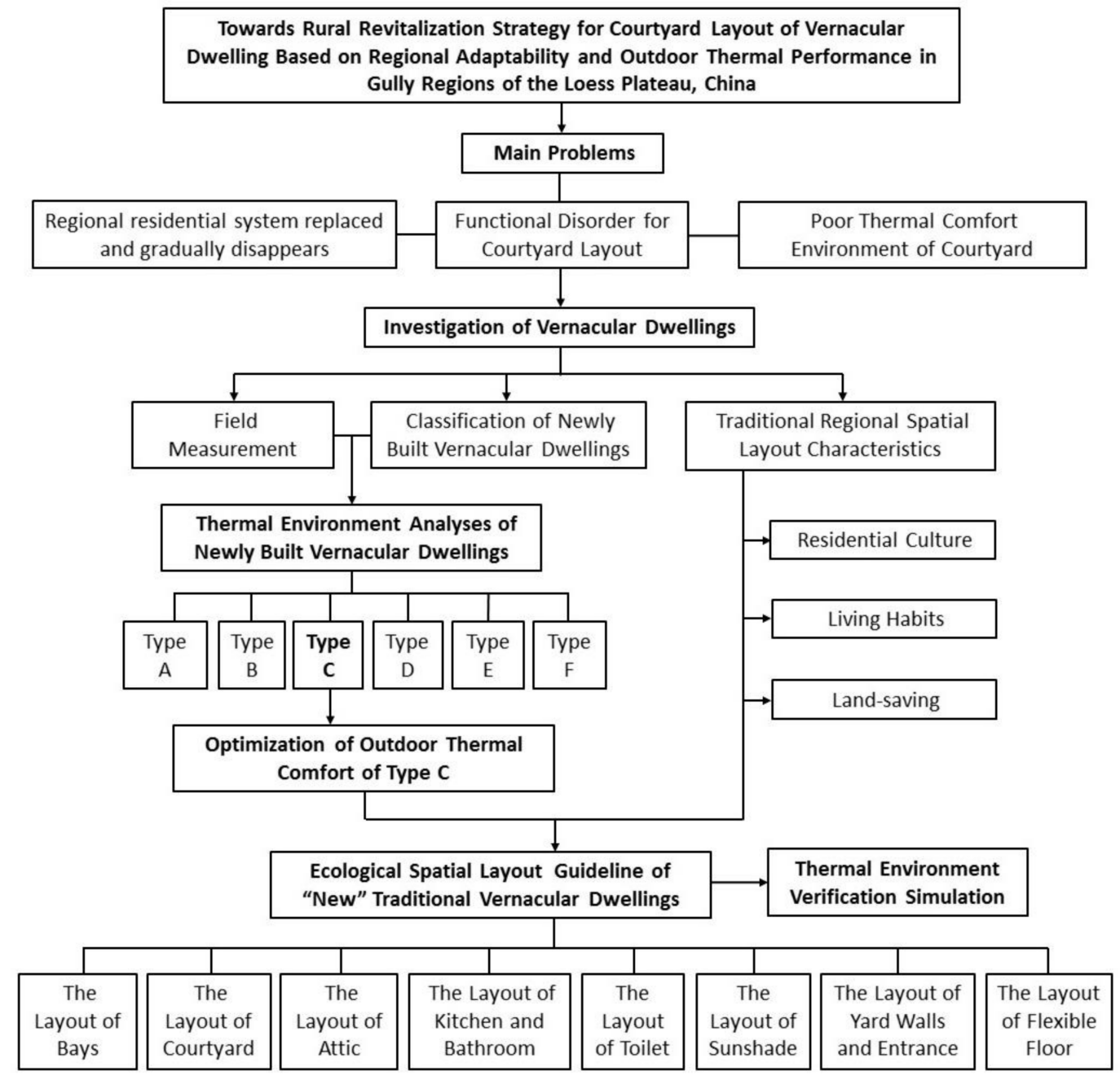

Figure 5. New approaches and research framework.

\subsection{Regional Spatial Layout Characteristics of Traditional Vernacular Dwellings}

Traditional vernacular dwellings refer to dwellings built according to traditional village construction methods. There are no architectural designers involved in the construction; instead, local artisans use their experience, knowledge, and heritage passed from generation to generation to design and build houses. Generally, these artisans are very familiar with the local materials and climate, and they can design and build low-cost houses with high suitability. Our field investigation was conducted over a period of 3 years in 4 major cities (Qingyang, Pingliang, Xianyang, and Baoji), 6 counties, 16 townships, and 51 villages in the Loess Plateau. According to the field investigation, we summarized several important local traditional architecture cultures, grasped the combination and balanced methods that local dwellings use and their climate adaptation, and the following characteristics of traditional vernacular dwellings are summarized.

\subsubsection{The Influence of Residential Culture on Vernacular Dwellings}

For a long time, the culture of being harmonious with nature and customs has been integrated into traditional vernacular dwellings. In China, rituals and ceremonies are used as the base of country management, and they are regarded as the regulations and rules that maintain the different relationships between social classes and social orders [33]. In ancient times, courtyard dwellings in China were built according to the traditional concepts of the five elements of metal, wood, water, fire, and earth, which were believed to comprise the universe [34]. The concept of the five elements originated in Taoism, and similar concepts 
appear in Feng Shui, which relates to the correlation between ecology, the environment, and the habitat [35].

In the past two thousand years, rituals and ceremonies have been carried out in the whole Chinese social life, and also have a deep influence on architecture. The layout of traditional vernacular dwellings in the gully region of the Loess Plateau also show this influence. The main room, as the most important building space, is the room located in the middle used to enshrine ancestors and as a living room for guest reception; the rooms located at each side of main room are bedrooms for elders. On each side of the courtyard, rooms are used as kitchens, storage, and bedrooms for the younger generations. Generally, the grading of the east side rooms is higher than that of the west. All of these layouts show the traditional Chinese ethical order, as shown in Figures 6 and 7.
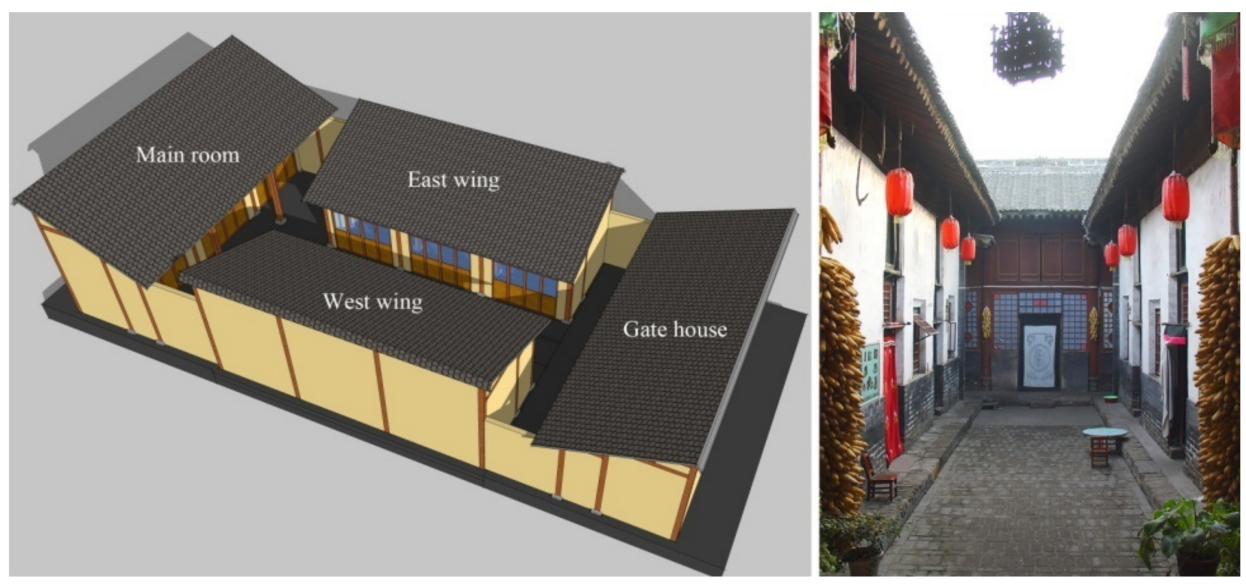

Figure 6. Space layout of traditional vernacular dwelling of the Loess Plateau.

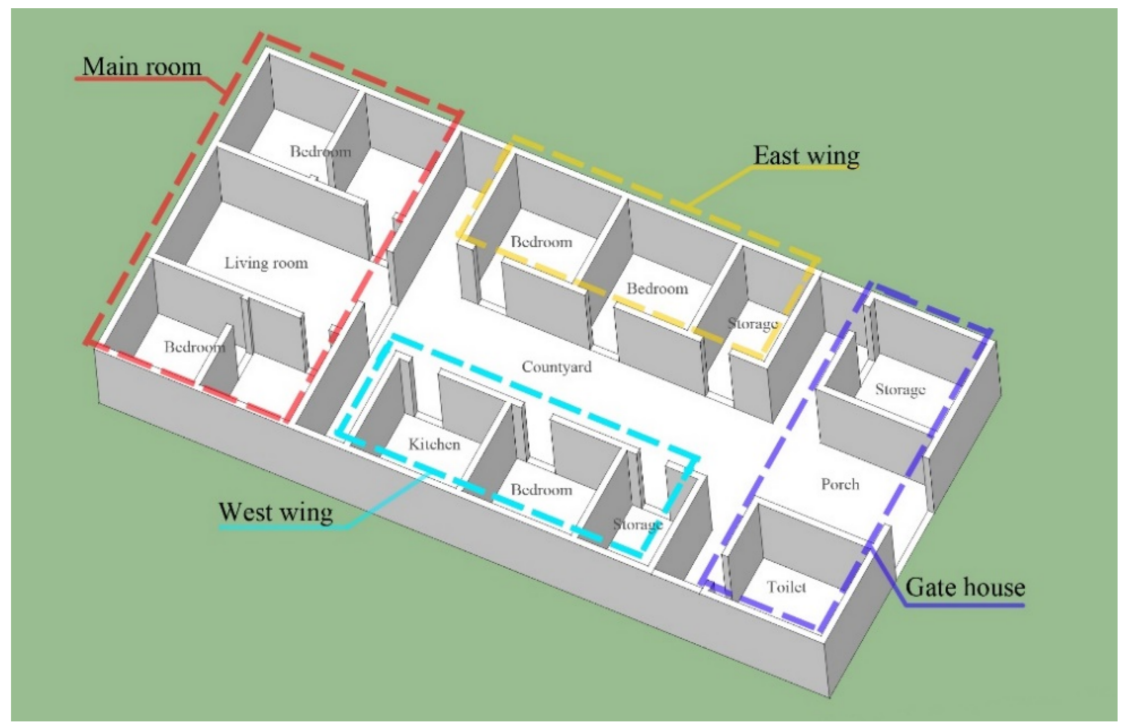

Figure 7. Division of space in traditional vernacular dwellings in the Loess Plateau.

When ancient human beings feel fear and gratitude to nature, they put themselves into the natural environment and try to live in harmony with it [36]. Over the course of the long evolution of traditional vernacular dwellings in gully regions, they have had a systematic impact on the environment, such as the climate, soil conditions, plants, rivers and so on, and some natural elements have also come to be their characteristics, such as backing onto the mountains and facing water and southern sunshine, which they called Feng Shui. 


\subsubsection{Traditional Thoughts about Land Saving}

Since ancient times, the Loess Plateau has been a place with the contradiction of high population density and limited cultivable land. For this reason, construction methods were developed to reduce construction land and maximize cultivable land. Courtyard dwellings on the Loess Plateau are usually called narrow yard dwellings, and the most unique point is the proportion of the courtyard. The length-width ratio of narrow yard dwellings is close to 3:1 [37]. This is different from most dwellings in northern China, the proportion of which is around 1:1, Figure 8.
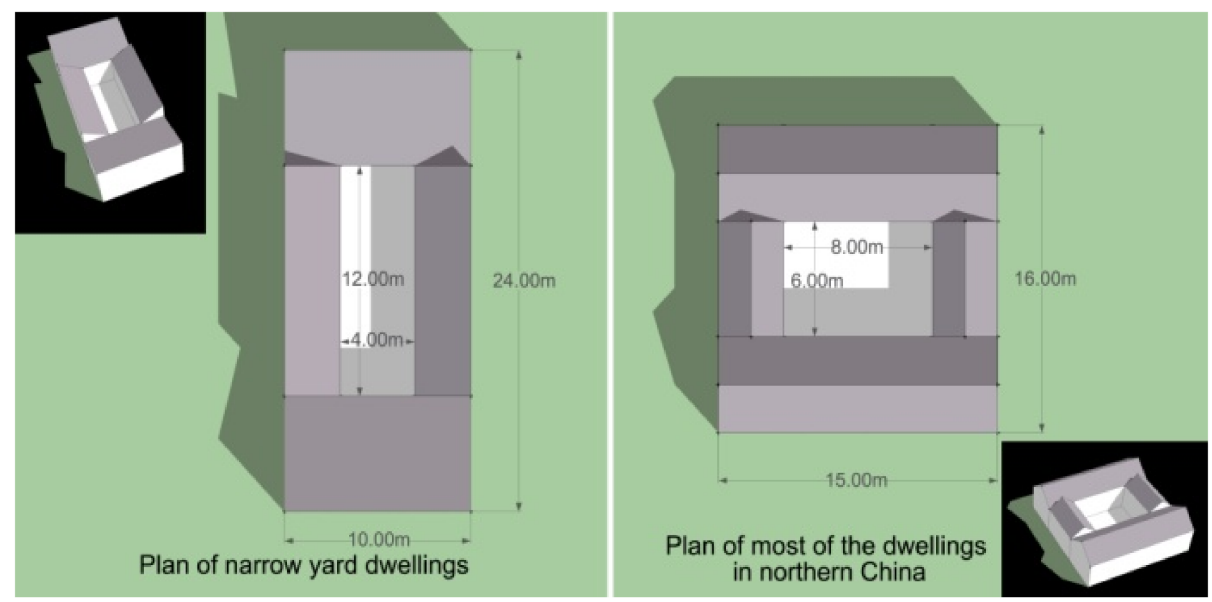

Figure 8. Comparison of the courtyards' proportions.

Compared with the same utilization area of ordinary dwellings in northern China, the width of narrow yard dwellings in gully regions is much narrower, but it can take more dwelling units in the same area, as shown in Figure 9. Thus, the use efficiency can be increased effectively, village land for construction can be saved, and a large amount of farmland can be retained through such initiatives.
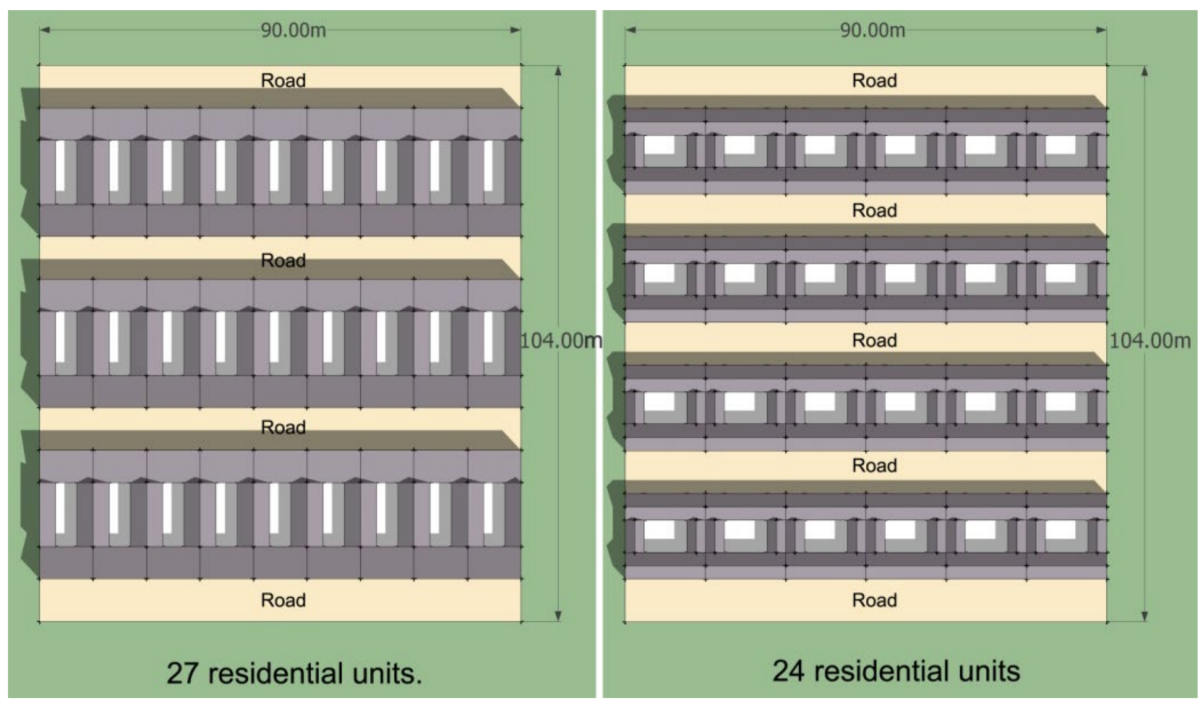

Figure 9. Number of residential units in a same-sized area in narrow yard dwellings and ordinary dwellings in northern China.

\subsubsection{The Influence of Living Habits on Vernacular Dwellings}

Courtyards are an important living and production space in traditional vernacular dwellings, and many daily activities are held there. Residents like to eat and take a rest in the courtyard, and women do daily housework there, such as washing, laundry, shoe, 
and making, and children also play there. Moreover, as an important production-assisting space, residents usually put their farming tools there, and park farming vehicles; they also raise livestock and plant vegetables there, Figure 10.

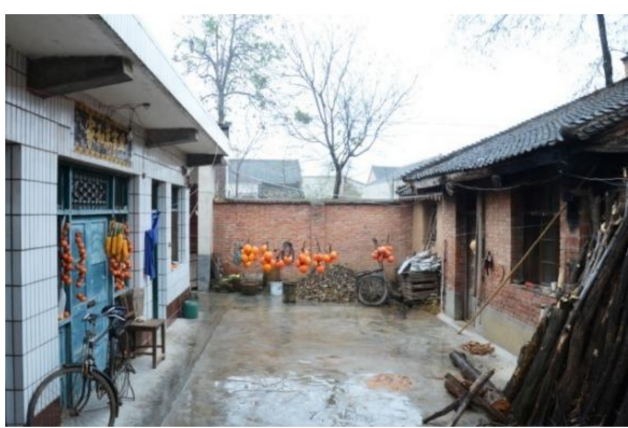

(a)

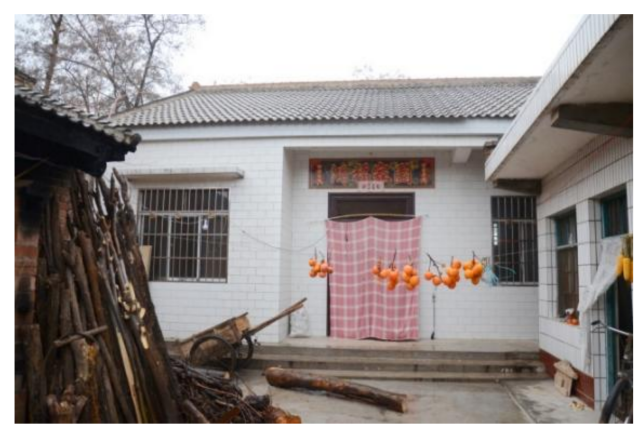

(b)

Figure 10. Typical courtyard in Qianyang County. (a) South side of courtyard. (b) North side of courtyard.

A sloped roof is commonly used in vernacular dwellings of gully regions in the Loess Plateau, and attics are very common there. On the one hand, attics can be used as temperature damping control areas, which have thermal and insulation functions for the indoor climate. On the other hand, the spacious space of the attic can be used to store farming tools, grains, and family debris, which is an important storage space within the house, Figure 11.

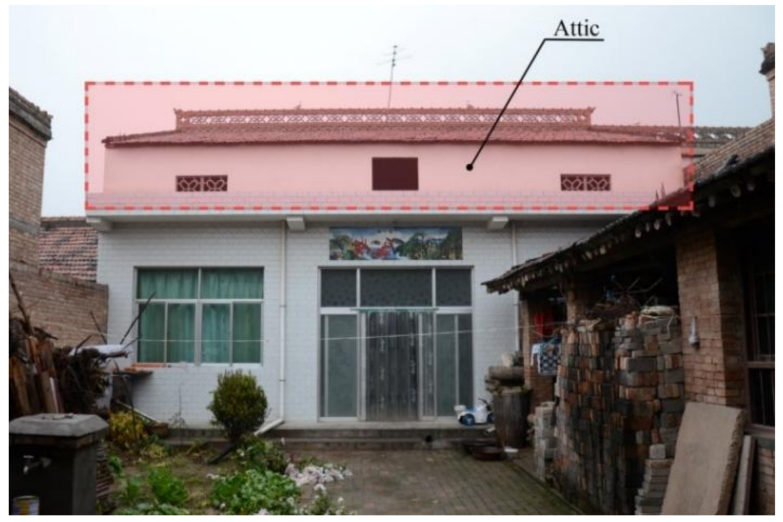

(a)

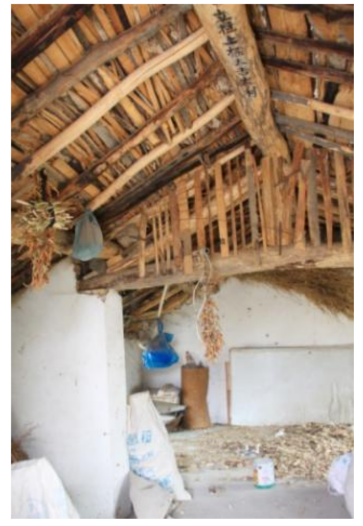

(b)

Figure 11. Attic space in typical vernacular dwellings. (a) Outside appearance of an attic. (b) Inside an attic.

\subsection{Field Measurement of Outdoor Thermal Environment in Newly Built Vernacular Dwellings}

During the field investigation, a very typical brick-concrete residential dwelling was chosen as the research object, located in Min Feng Village, Jian Jun Town of Yong Shou County in Shaanxi Province. In the courtyard, the thermal environment fluctuation was relatively large, and it does not have the function of adjusting the local climate on a small scale. For the field measurements, the inside and outside temperature of the courtyard were measured in the coldest month and hottest month of one year, respectively. We took measurements in fixed points inside and outside the courtyard, respectively. The temperature was measured every $2 \mathrm{~h}, 12$ times in 1 day and continuously for 3 days using a thermos recorder; the model number is TR-72nw, produced by T\&D; the results are shown in Figures 12 and 13. After recording and collecting the field measurement data, the highest, lowest, and average temperature, shown in Table 3, were drawn according to the average temperatures in each measurement time. 


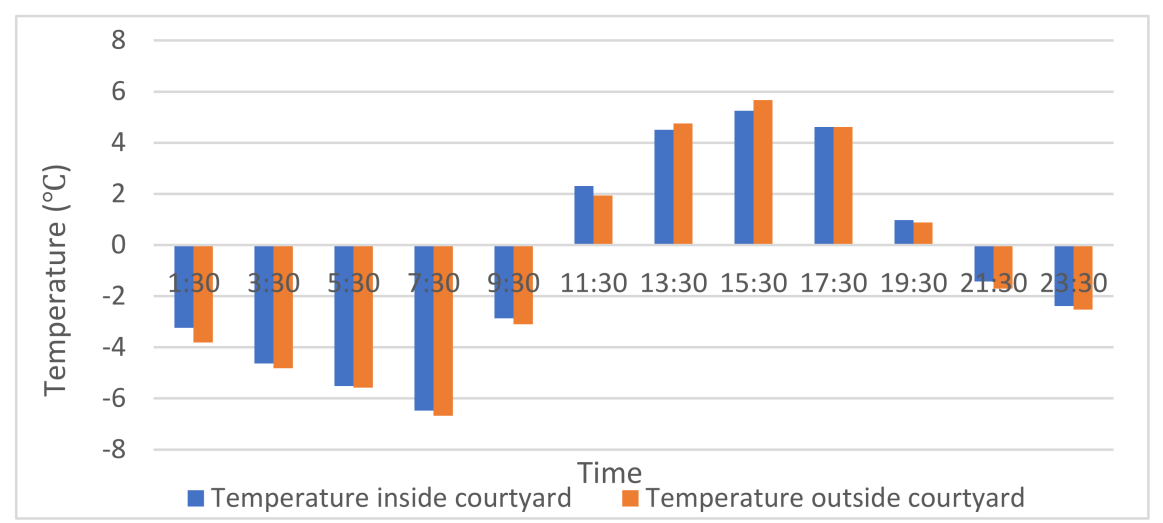

Figure 12. Temperature inside and outside courtyard in January 2020.

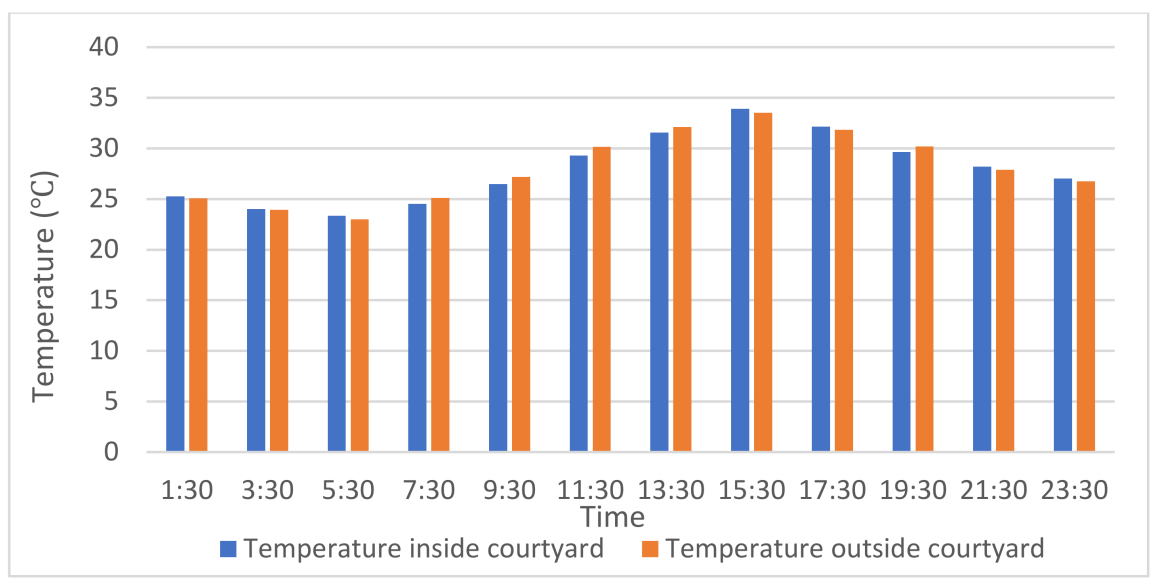

Figure 13. Temperature inside and outside the courtyard in July 2020.

Table 3. Temperature inside and outside the courtyard in 2020.

\begin{tabular}{|c|c|c|c|c|c|c|}
\hline & \multicolumn{2}{|c|}{$\begin{array}{l}\text { Average Temperature } \\
\qquad\left({ }^{\circ} \mathrm{C}\right)\end{array}$} & \multicolumn{2}{|c|}{$\begin{array}{c}\text { Highest Temperature } \\
\left({ }^{\circ} \mathrm{C}\right)\end{array}$} & \multicolumn{2}{|c|}{$\begin{array}{l}\text { Lowest Temperature } \\
\qquad\left({ }^{\circ} \mathrm{C}\right)\end{array}$} \\
\hline & January & July & January & July & January & July \\
\hline $\begin{array}{l}\text { Inside } \\
\text { courtyard }\end{array}$ & -0.73 & 27.96 & 5.25 & 33.92 & -6.48 & 23.36 \\
\hline $\begin{array}{l}\text { Outside } \\
\text { courtyard }\end{array}$ & -0.86 & 28.07 & 5.67 & 33.52 & -6.68 & 23.01 \\
\hline
\end{tabular}

According to the data, the temperature inside and outside the courtyard walls was almost the same; the difference was within $1{ }^{\circ} \mathrm{C}$ in both summer and winter. It was thus obvious that courtyard plays no effects on the thermal performance of the outdoor courtyard.

\subsection{Classification of Newly Built Vernacular Dwellings}

During the new countryside construction, the courtyards of vernacular dwellings were gradually unified by the form of models [38]. There are mainly two reasons for this: one is that under the influence of urbanization trends of some other developed areas, modern vernacular dwelling designs entered the gully regions; the other is that peoples' lifestyles and productivity forms are relatively similar now, and courtyard functions are almost the same.

In this context, in order to carry out the further research on current newly built vernacular dwellings, we conducted a number of field investigations. In the new countryside constructions, the cover areas are from $200 \mathrm{~m}^{2}(0.30 \mathrm{mu})$ to $267 \mathrm{~m}^{2}(0.40 \mathrm{mu})$; the height of 
main building is usually $4.5 \mathrm{~m}$ to $5.4 \mathrm{~m}$; subsidiary rooms are $3.3 \mathrm{~m}$ to $3.6 \mathrm{~m}$; and courtyard walls are $2.4 \mathrm{~m}$ to $2.7 \mathrm{~m}$, as shown in Figure 14 .

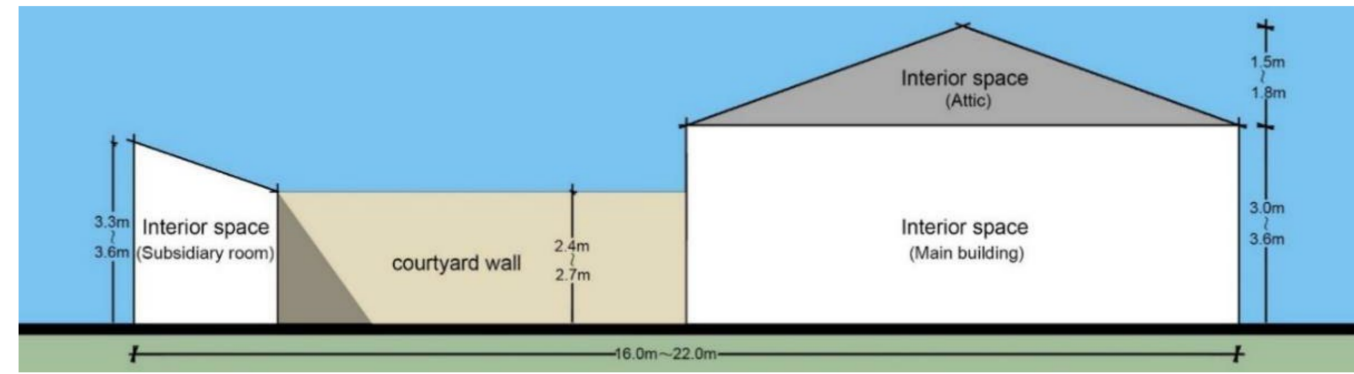

Figure 14. Proportion and scale of vernacular dwellings.

The house bay for most newly built vernacular dwellings is $3.30 \mathrm{~m}$ or $3.60 \mathrm{~m}$ with two types: three bays and four bays. According to courtyards' location, vernacular dwellings can be further divided into foreyard type, backyard type, and both foreyard and backyard type. The courtyard located on the side of the main entrance is the foreyard, and the other side is called the backyard. Combining the above two factors, the vernacular dwellings in gully regions can be mainly divided into the following six types shown in Tables 4 and 5 .

Table 4. Vernacular dwelling courtyard types.

\begin{tabular}{ccc}
\hline Courtyard Types & Bay Number & Courtyard Locations \\
\hline Type A & 3 & Foreyard \\
Type B & 3 & Backyard \\
Type C & 3 & Both foreyard and backyard \\
Type D & 4 & Foreyard \\
Type E & 4 & Backyard \\
Type F & 4 & Both foreyard and backyard \\
\hline
\end{tabular}

Table 5. Typical dwelling of each type.

Type A


Table 5. Cont.

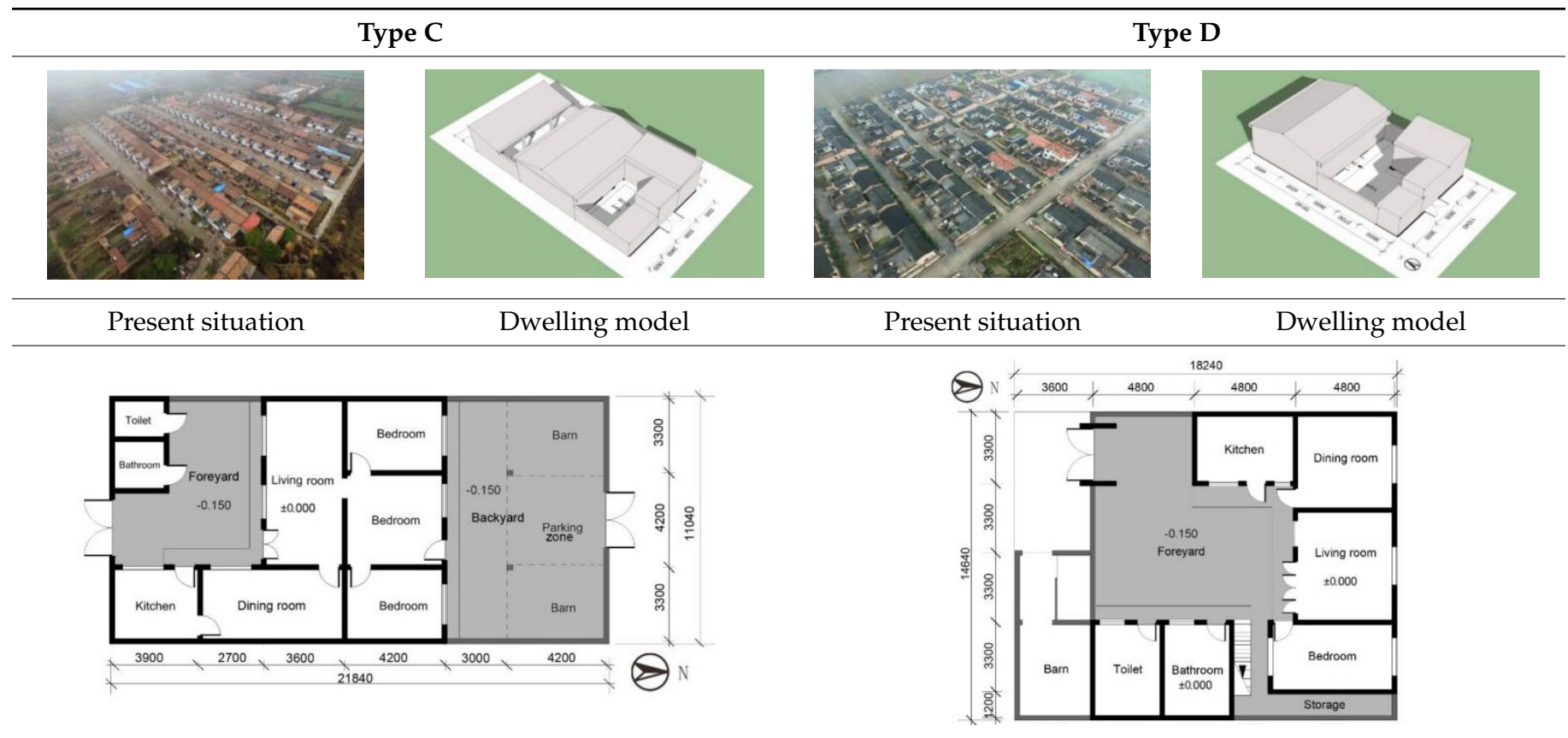

Dwelling plan in Shi Jia Nian village of Yong Shou County Type E

Dwelling plan in Wang Jia Zhuang of Qian Yang County

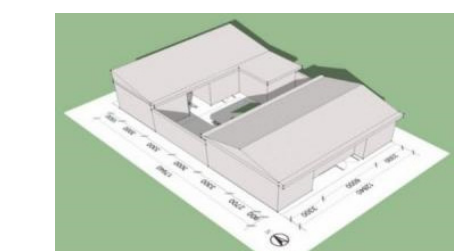

Type F
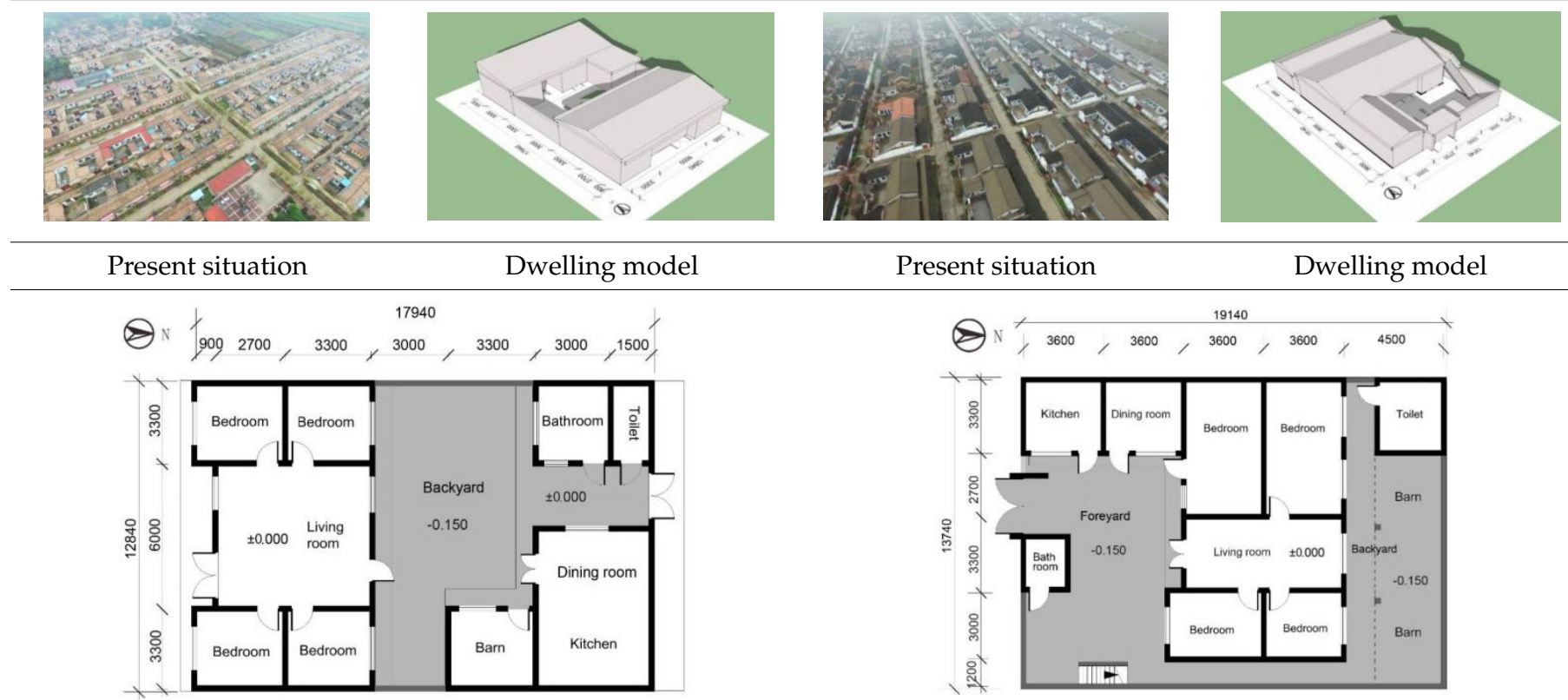

Dwelling plan in Zhu Jie village of Yong Shou County

Dwelling plan in Long Quan Si village of Qian Yang County

According to the classification of different dwellings, a simplified model of each typical dwelling can be depicted as shown in Figure 15. By combining Figure 15 (diagram of vernacular dwellings types) with the field investigation, simplified models of the six different types vernacular dwellings were made, which cover an area of $240 \mathrm{~m}^{2}$. For three bays, Type A, Type B, and Type C, the length is $20 \mathrm{~m}$ and the width is $12 \mathrm{~m}$. For four bays, Type $\mathrm{D}$, the length is $16 \mathrm{~m}$ and the width is $15 \mathrm{~m}$. Both the courtyard and main residential building are $120 \mathrm{~m}^{2}$. The main residential building is a brick and concrete structure, and the height is $4.5 \mathrm{~m}$. The ground material in the courtyard is concrete, and the courtyard wall is a $2.7 \mathrm{~m}$ brick wall. 


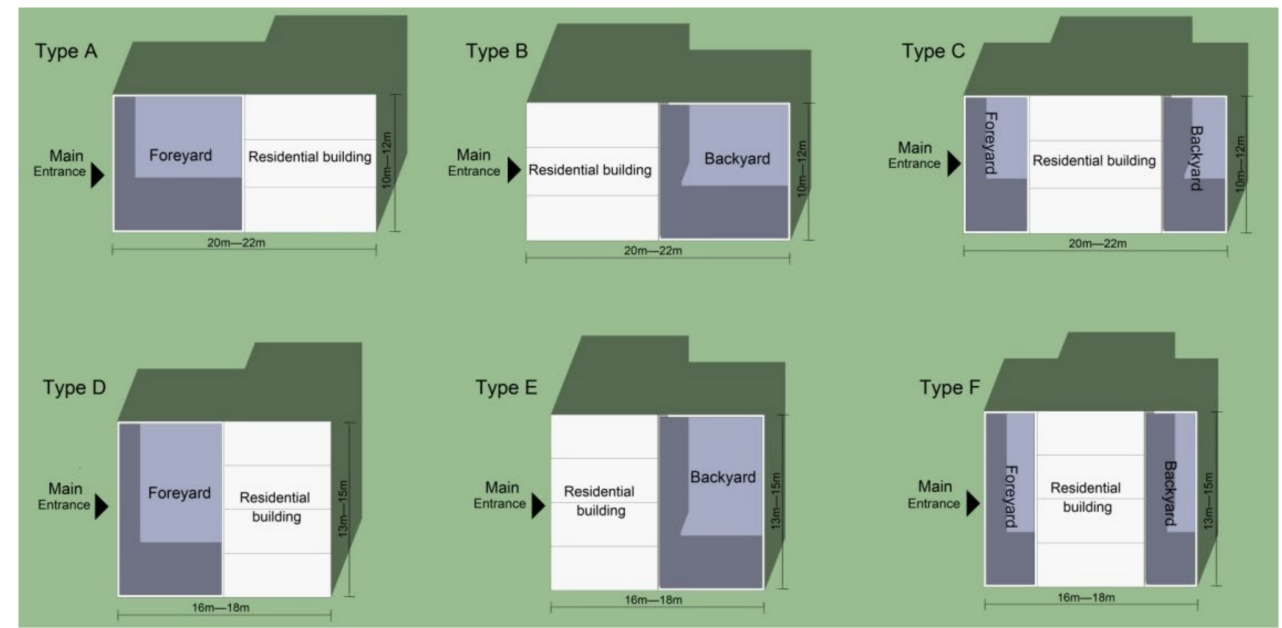

Figure 15. Diagram of vernacular dwellings types.

\subsection{Simulation Method}

Rhino/Grasshopper is one of the most widely used platforms used by designers today. Ladybug offers several advantages that are currently not offered by other existing Rhino/Grasshopper-related environmental design plugins, and we imported standard EnergyPlus Weather files (EPW) into Grasshopper, which provided a variety of 2D and $3 \mathrm{D}$ designer-friendly interactive graphics to support the decision-making process during the initial stages of design $[39,40]$. Moreover, due to the simplified analysis process, automated calculations, and graphical visualizations in the 3D modelling interface of Rhino/Grasshopper, that of Ladybug is more easily understood [41]. Combined with parametric tools, Grasshopper allows almost instantaneous feedback on design modifications, and the information and analysis are also interactive.

In this study, the advantages of function setting were analyzed and described in detail, and the relevant design practices were also systematically analyzed. The Ladybug tool's script is described in detail by G. Evola et al. [42]. The workflow components of this study were compiled from the literature [42-44]. This study mainly researched the influence of spatial layout on the outdoor microclimate within courtyards, so the thermal exchange between the facade, indoors, and outdoors was not considered.

We modelled six typical courtyards in a Grasshopper plug-in shown as Figure 16, and use the components shown in Figure 17 to transform the fence and building blocks of the model into a "building zone", buildings consisting of simple blocks without distinguishing transparent and opaque parts of the envelope.

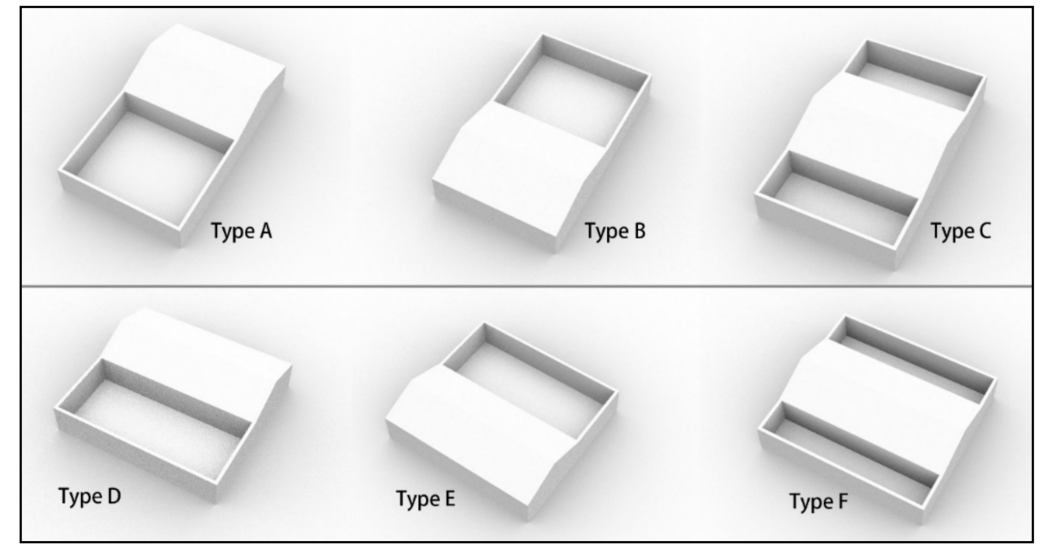

Figure 16. Six typical courtyards. 


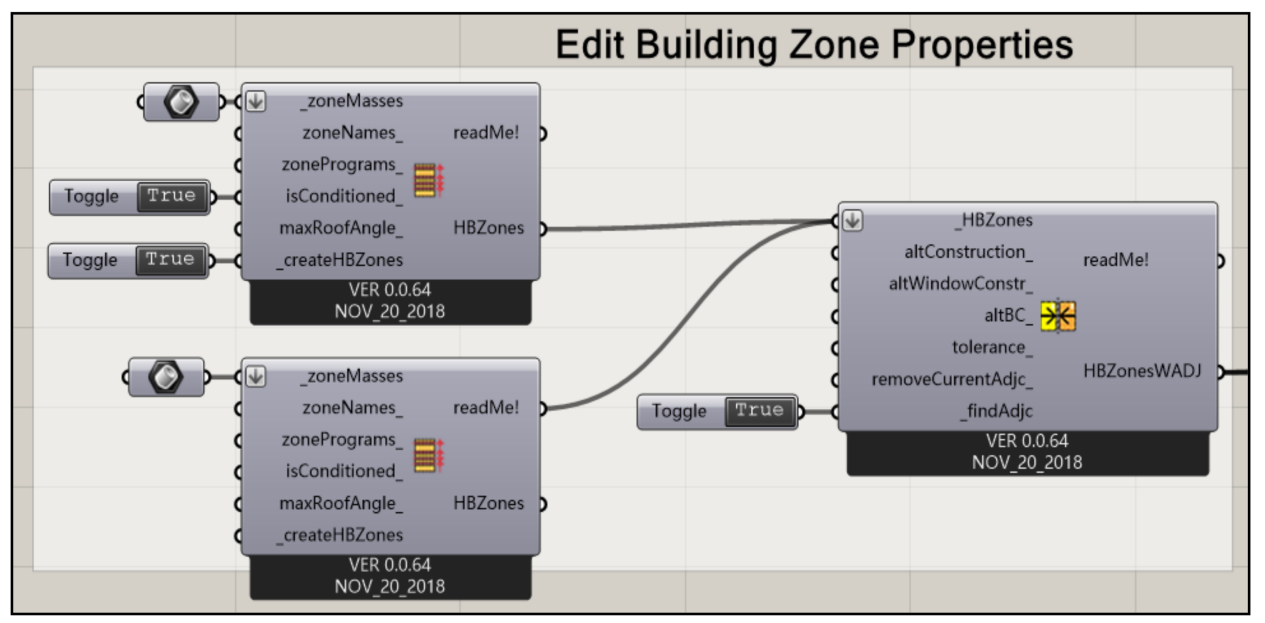

Figure 17. Setting up "Building zone".

Then we use the components shown in Figure 18 to set "ground zone". According to the field investigation, courtyard floor is defined as "ground zone", using a volumetric composition with no internal gains and the material defined as "4-concrete". The vegetation condition was estimated from field observations with a canopy diameter of $3 \mathrm{~m}$. The vegetation was simplified to a cube of comparable size to the canopy diameter, and different transmittance was used to simulate seasonal variations in tree foliage sparseness, with transmittance set to 0.3 in summer and 0.8 in winter. The measurement plane is set at a height of $1.5 \mathrm{~m}$ inside the compound with a grid size of $0.5 \mathrm{~m} \times 0.5 \mathrm{~m}$.

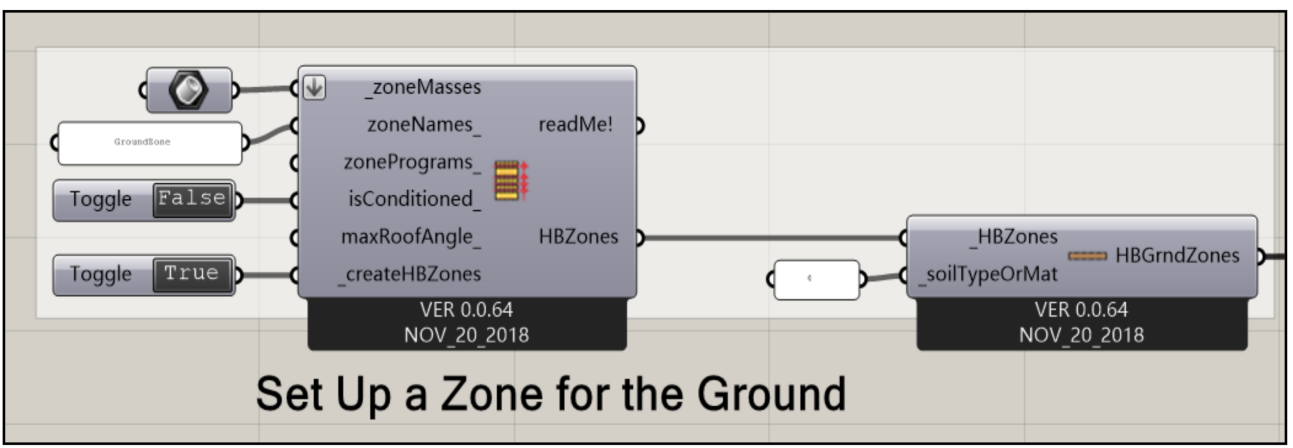

Figure 18. Setting up "ground zone".

The outdoor climate parameters were simulated by the set-up courtyard model through the Openstudio platform of Honeybee plug-in. The meteorological conditions in the Yan'an area were chosen as the boundary conditions for this simulation. For the performance simulation, the meteorological data of Yan'an area derived from the Chinese Standard Weather Data (CSWD) [5] were selected as the boundary conditions for simulation. The hottest month in summer is July, the highest temperature is around $37.5^{\circ} \mathrm{C}$, the average temperature is $23.89{ }^{\circ} \mathrm{C}$, the coldest month in winter is January; the lowest temperature is $-18.1^{\circ} \mathrm{C}$, and the average temperature is $-4.57^{\circ} \mathrm{C}$. Therefore, the average radiant temperature inside the courtyard in July and January was chosen as the comparison index for summer and winter respectively, to analyze the thermal effects by different kinds of courtyard layout.

The outdoor climate simulation results were then plugged into the outdoor thermal comfort analysis plug-in in Honeybee to obtain and visualize the average radiant temperature data. In order to more accurately reflect the real feelings of occupants, the measurement plane is set at $1.5 \mathrm{~m}$ height inside the compound with a grid size of $0.5 \mathrm{~m} \times$ $0.5 \mathrm{~m}$. 
Most households have plants in their courtyard, thus we simulated vegetation effects on thermal comfort within courtyard in different seasons. The vegetation condition was estimated from field observations with a canopy diameter of $3 \mathrm{~m}$. To simplify the calculation, the vegetation was simplified to a cube of comparable size to the canopy diameter, and different transmittance was used to simulate seasonal variations in tree foliage sparseness, with transmittance set to 0.3 in summer and 0.8 in winter.

\section{Results}

\subsection{Thermal Environment Simulation of Newly Built Vernacular Dwellings}

4.1.1. Comparative Analysis of Six Courtyard Types

Although the gully region of the Loess Plateau belongs to the cold area within the Chinese climate partition, the summer is also very hot. The prevailing wind in summer is the southeast monsoon, and in winter, it is the northwest monsoon. Especially in winter, the dominant wind from the northwest is mixed with dust, which causes a poor wind environment within the courtyard. The simulation shows the radiation temperature of the courtyard space at a height of $1.5 \mathrm{~m}$ in January and July [45], as shown in Table 6.

Table 6. Thermal environment analyses of newly built vernacular dwellings.

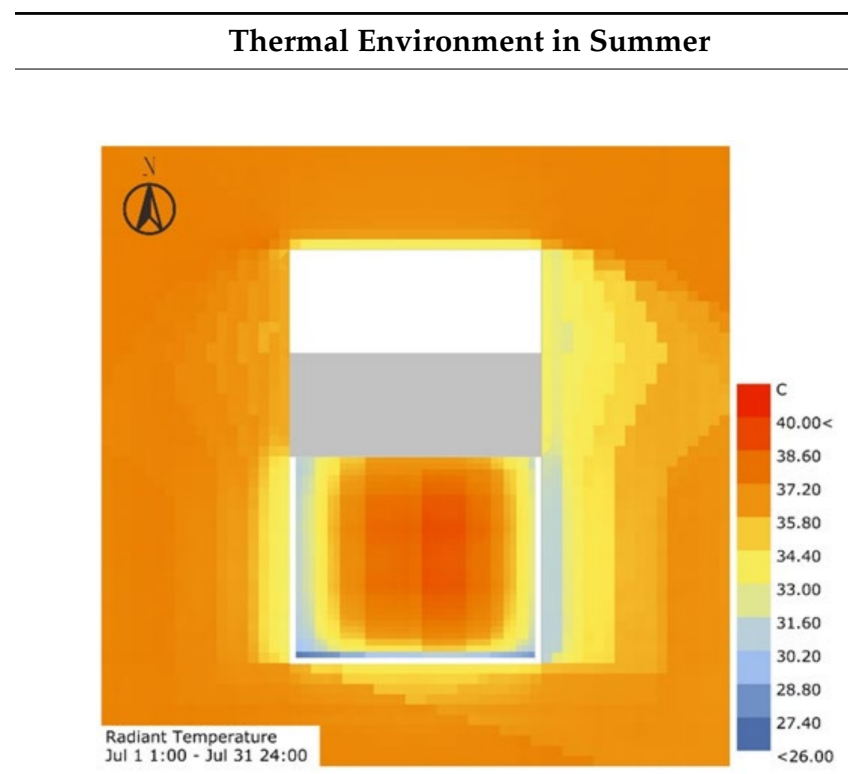

\section{Thermal Environment in Winter}

Type A

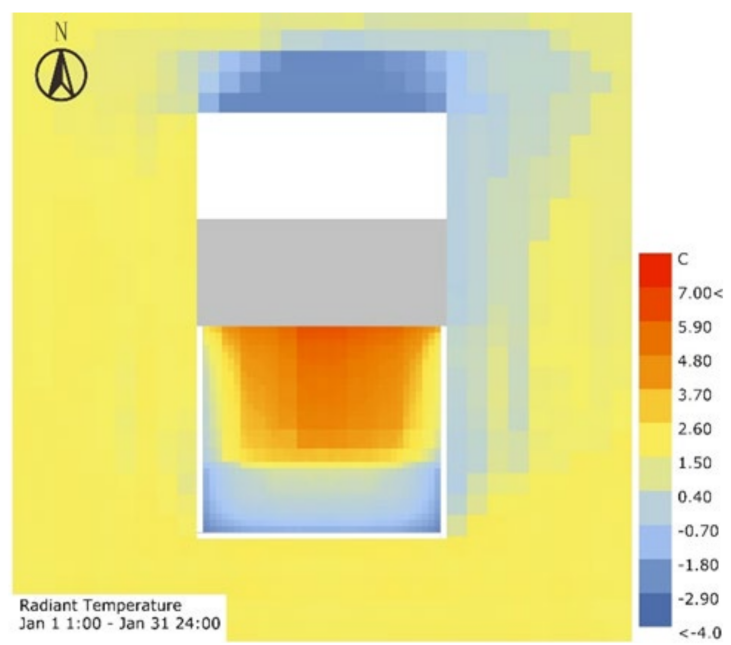

Type B
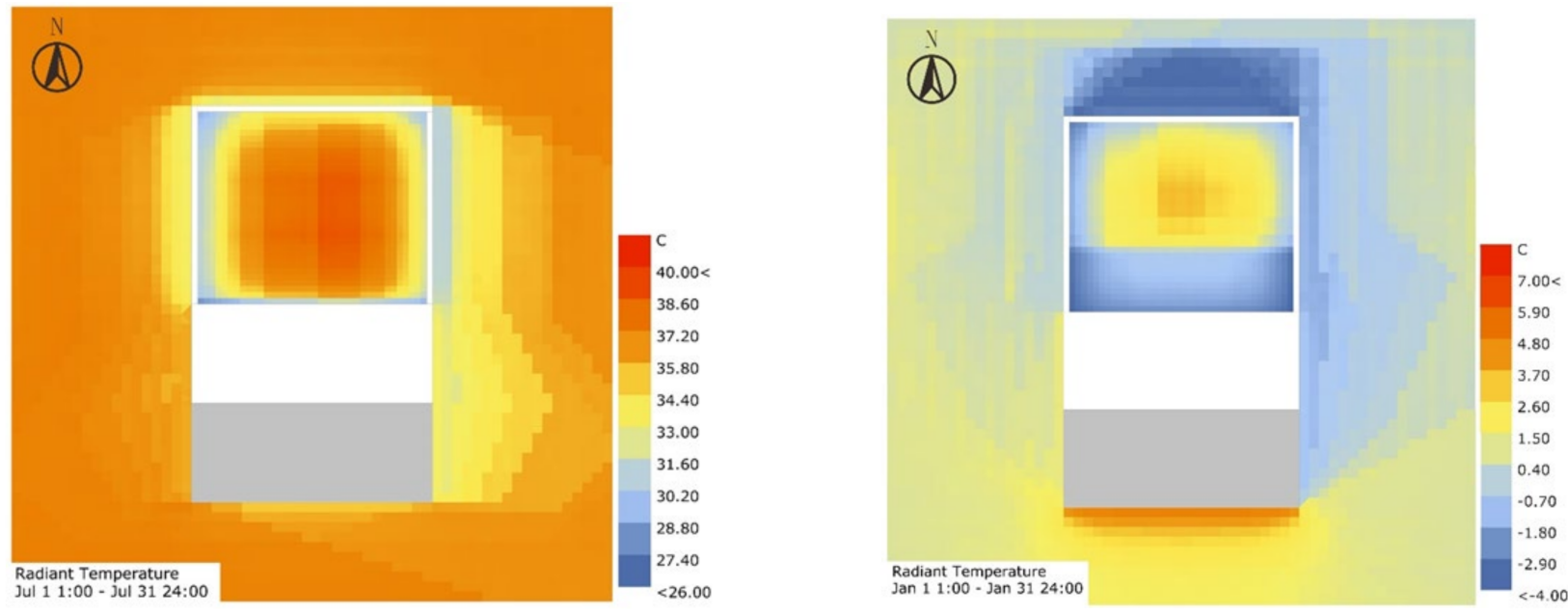
Table 6. Cont.

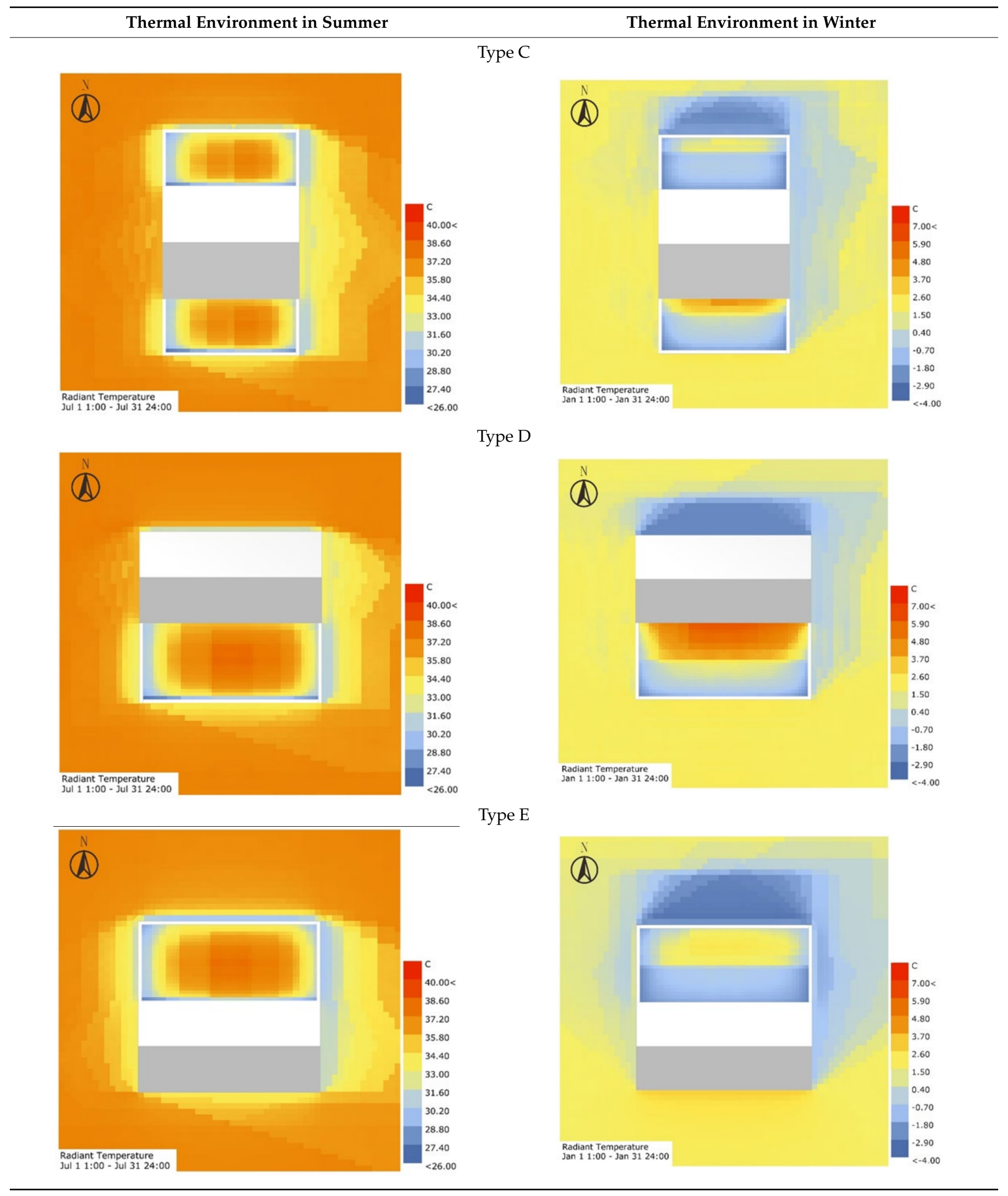


Table 6. Cont.

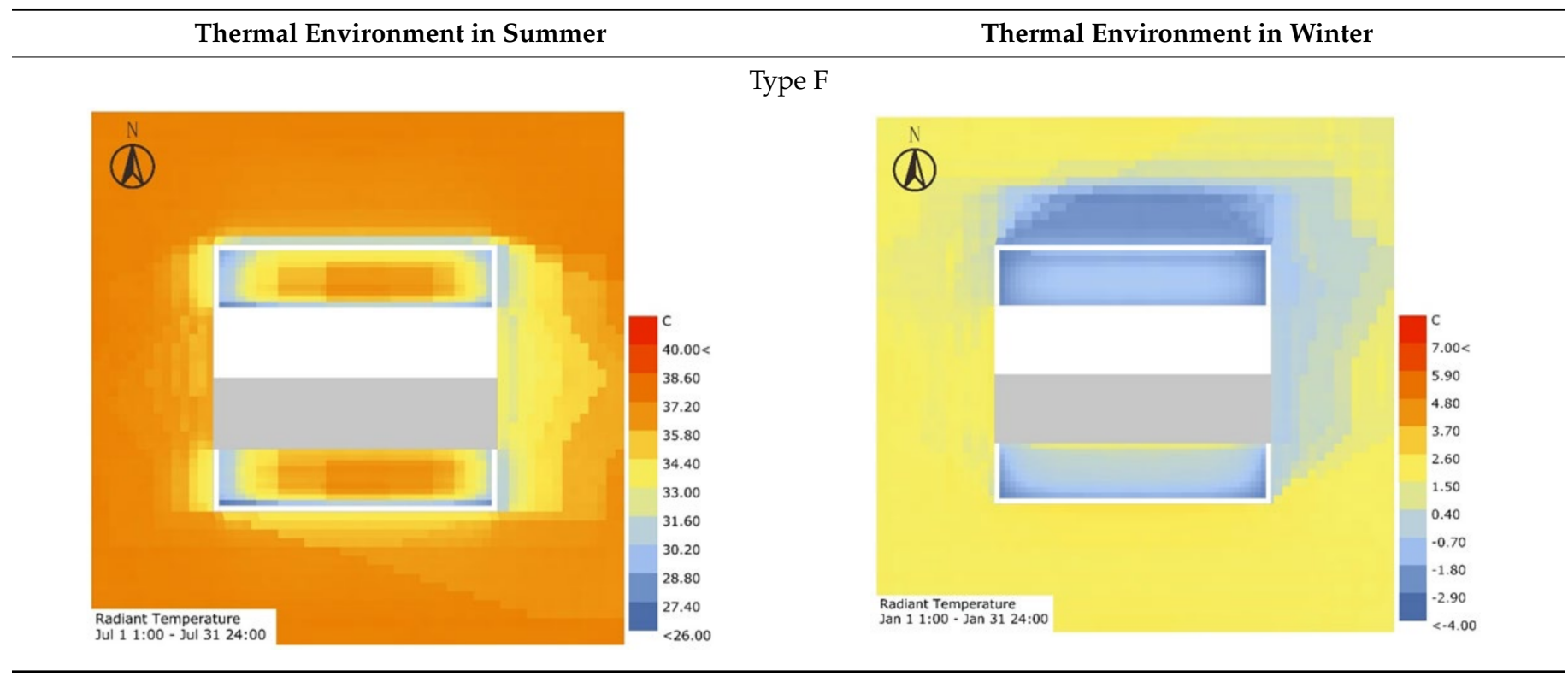

The simulation results of the thermal environment by dwelling unit show that:

(1) In summer, the thermal environments within the Type A and Type D courtyards with a front courtyard, and Type B and Type E with a backyard, are almost the same, and all of them are very hot. The main reason is the relatively large courtyard area, and the weak sunshine shielding influence by courtyard walls.

(2) In winter, the thermal environment within the Type A and Type D courtyards with front a courtyard is obviously superior to that of Type B and Type E with a backyard. In the backyard type, the courtyard is located to the north of the main residential building. Because of the relatively low solar altitude in winter, residential buildings cause a fielding impact on the north backyard; thus, the yard temperature in Type B and Type E courtyards is relatively low. However, the main building in Type A and D is designed without a backyard as a buffer and faces the cold northwest wind directly, which causes a large amount of thermal energy loss and is not good for thermal insulation. Therefore, the design of the backyard is very important for insulation and energy saving for the main buildings.

(3) For Type $\mathrm{C}$ and $\mathrm{F}$ with both a foreyard and backyard, the thermal environment of summer is better than that of the other four types. This is because the courtyard in these two types is divided into two parts; the area of each part is relatively small, and the shading effect caused by residential buildings and courtyard walls is relatively high. However, for the same reason, the thermal environment in the front courtyard of these two types of courtyards in winter is worse than the foreyard of Type A and Type D, which only have foreyard, and the thermal environment in the backyard is worse than the backyard of Type B and Type E, which only have backyard. All in all, the thermal environment of Type $\mathrm{C}$ and $\mathrm{F}$ with both a foreyard and backyard is much better than that of the other four types. Moreover, the courtyards' productivity and living-related functions are much clearer and easier for residents to use.

(4) Compared with Type F, besides land saving, Type C has better daylighting; the reason is the fact that, in the same construction land area, the courtyard width of Type F from south to north is too narrow, and the east-to-west side is too long, which is not good for daylighting. The longer distance from south to north in Type C supplies more space for the courtyard, which is not only good for daylighting, but also provides a more pleasant scale for the courtyard space.

(5) In conclusion, in the gully regions of the Loess Plateau, vernacular dwellings with both a foreyard and backyard are good for creating a better thermal environment, 
and good for insulation and energy saving. Moreover, the size and proportions of the courtyard and the height of the walls play an important role for the wind environment throughout the whole courtyard [46]. In the six types, the courtyard layout of Type C has a relatively better thermal environment than that of the others.

\subsubsection{Optimization of Outdoor Thermal Environment of Type C}

Based on the above analysis, in order to further optimize the thermal performance of Type C, different yard walls of $1.8 \mathrm{~m}$ and $3 \mathrm{~m}$ with or without trees were designed and the thermal environments were, respectively, simulated. According to the monsoon in the gully regions, local broad-leaved trees around $4 \mathrm{~m}$ high and with a $2 \mathrm{~m}$ crown diameter are planted in the southeast of the foreyard and the northwest of the backyard in the Type $\mathrm{C}$ vernacular dwellings, respectively. The simulation results are shown in Table 7:

Table 7. Thermal environment analyses of Type $\mathrm{C}$ in different situations.

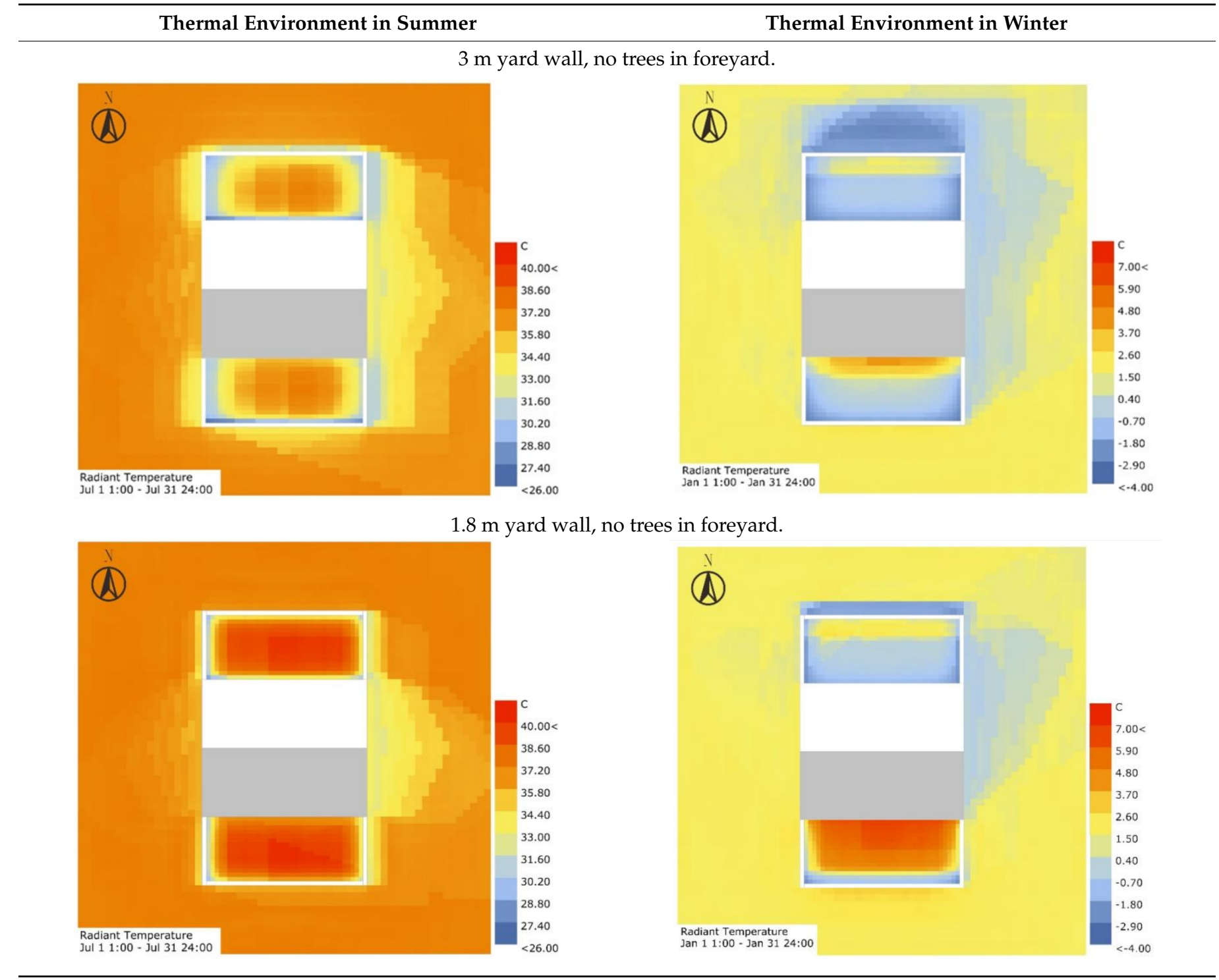


Table 7. Cont.

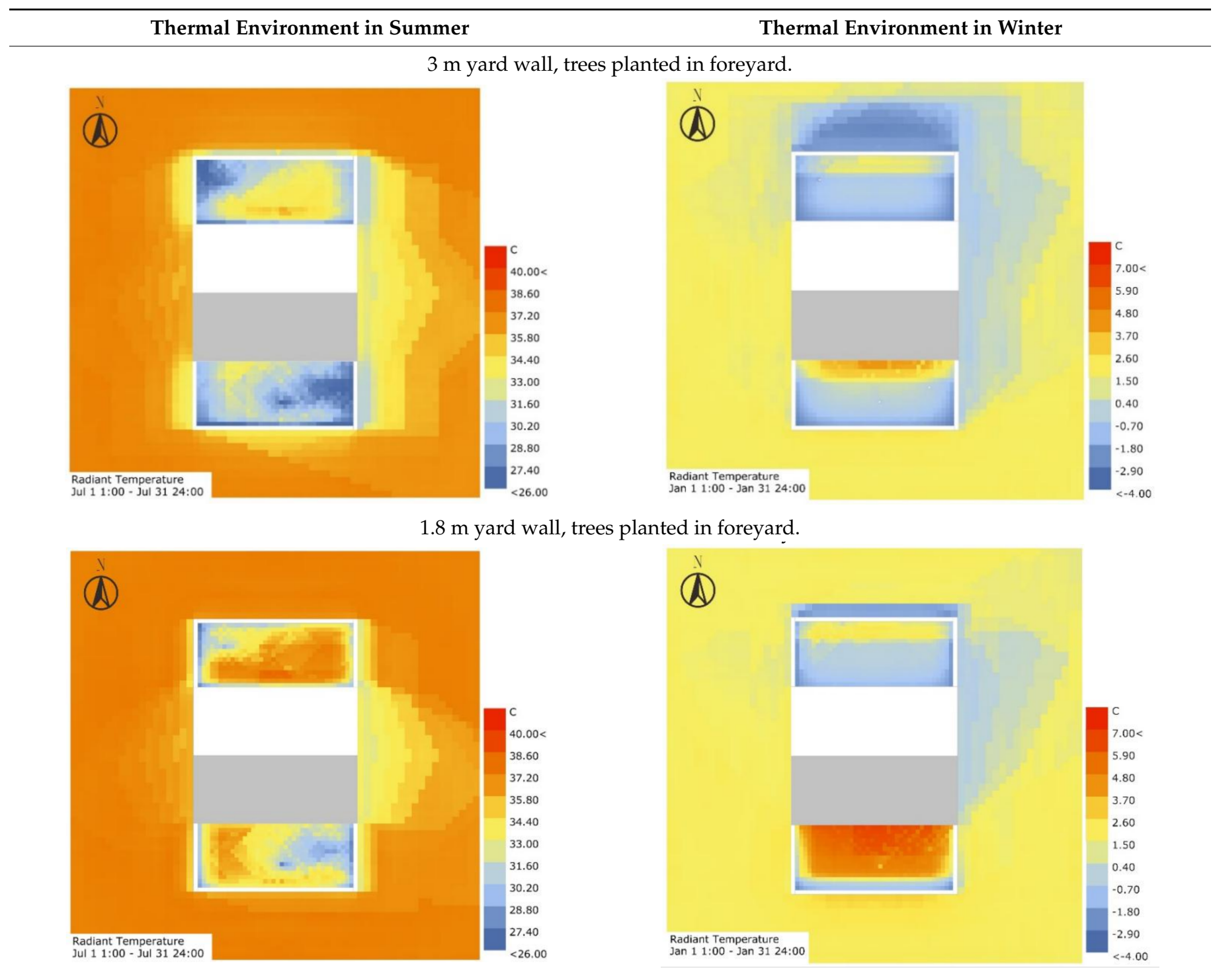

The simulation results show that:

(1) Without trees, when the walls of the foreyard and backyard were designed as $3 \mathrm{~m}$, due to the shading effect, the thermal environment in both the foreyard and backyard was better than that of the $1.8 \mathrm{~m}$ walls in summer. However, in winter, when the walls were $3 \mathrm{~m}$, the thermal environment in the foreyard was worse than the walls designed as $1.8 \mathrm{~m}$. For the thermal environment of the backyard, there was no obvious difference when walls were $3 \mathrm{~m}$. In addition, in order to prevent large energy consumption caused by the prevailing northwest monsoon in winter, the northwest backyard wall should be higher to avoid the cold wind.

(2) In summer, regardless of whether the yard walls were $3 \mathrm{~m}$ or $1.8 \mathrm{~m}$, the thermal environment within the courtyard with planted trees was better than those with no trees. In winter, there were no leaves on the broad-leaved trees; thus, there was no impact on the thermal environment within the courtyard. It is thus proved that planting trees appropriately leads to a significant improvement on the thermal environment within the courtyard.

(3) Therefore, for the recommended Type $C$ vernacular dwellings, the thermal environment within the courtyard can be largely improved by reducing the southeast 
courtyard's wall height and increasing the northwest walls' height. Trees also should be appropriately planted in the southeast of the foreyard.

\subsection{Ecological Spatial Layout Guidelines for Tradition-Based New Vernacular Dwellings}

Based on the thermal environment analyses of newly built vernacular dwellings and traditional regional spatial layout characteristics, we propose an ecological spatial layout of tradition-based new vernacular dwellings, as follows.

\subsubsection{Bays in Vernacular Dwellings}

Three-bay and four-bay dwellings are the most common types of the newly built vernacular dwellings in gully regions. Nowadays, land resource for construction is very limited, and the area for vernacular dwellings has decreased from earlier courtyard areas of $267 \mathrm{~m}^{2}$ (around $0.4 \mathrm{mu}$ ) or $333 \mathrm{~m}^{2}$ (around $0.5 \mathrm{mu}$ ) to the current area of $0.3 \mathrm{mu}$ (200 square meters) and $0.35 \mathrm{mu}\left(233 \mathrm{~m}^{2}\right)$. In this research, the traditional courtyard layout was as follows: the current three-bay courtyard has the characteristic of saving land, Figure 19. Besides land saving, in the same construction land area, the daylighting in the three-bay courtyard is much better than that of the four-bay courtyard due to its narrow width from south to north and its length from east to west. Moreover, the longer distance from south to north in the three-bay vernacular dwellings supplies more space for the courtyard. Considering the courtyard area and the practicality of the architectural space, the size of the bay should be $3.3 \mathrm{~m}$ and $3.6 \mathrm{~m}$.
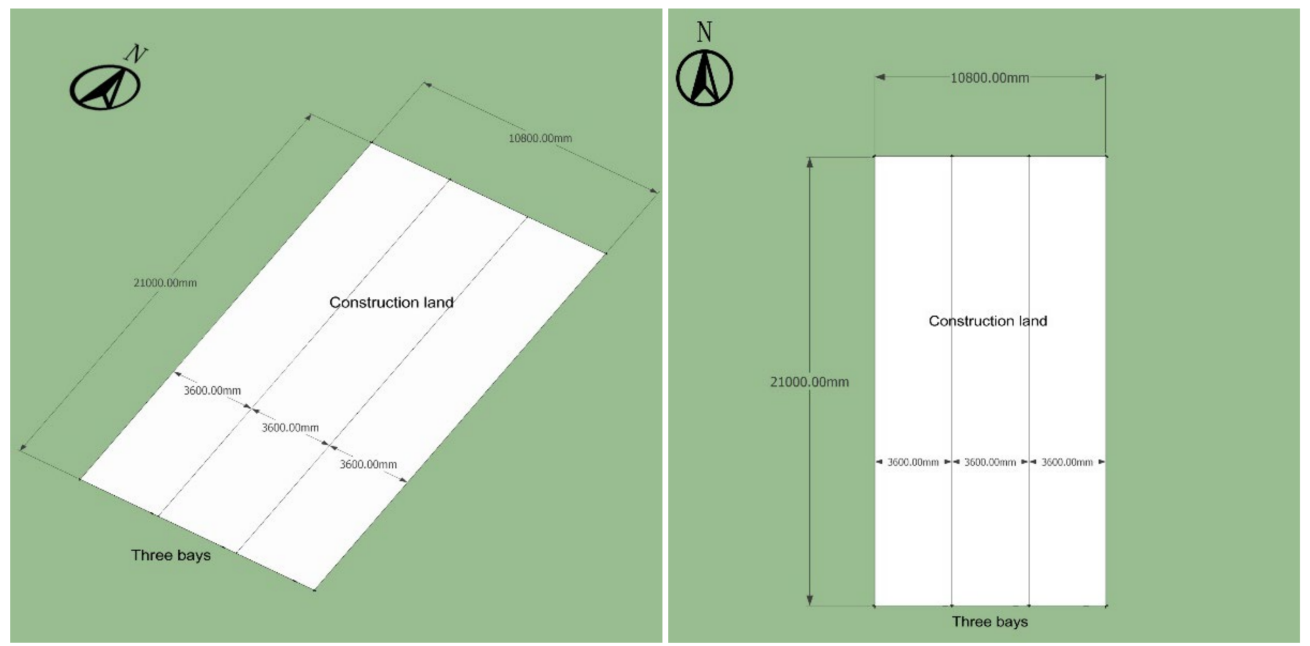

Figure 19. Diagram of three-bay vernacular dwelling.

\subsubsection{The Layout of the Courtyard}

Thermal performance in the courtyard is determined by microclimatic factors, particularly solar radiation and wind; the effect of these parameters may be evaluated with respect to the courtyard's orientation and geometrical properties so as to provide appropriate thermal comfort in the courtyard [47]. In this regard, the courtyard dimensions, the position of the rooms, and the orientation in Chinese traditional courtyards are important aspects influencing air speed (wind) and thermal comfort [48].

Vernacular dwellings with both a foreyard and backyard have the advantages over dwellings with only a foreyard or backyard, and also overcome their respective weaknesses, Figure 20. 

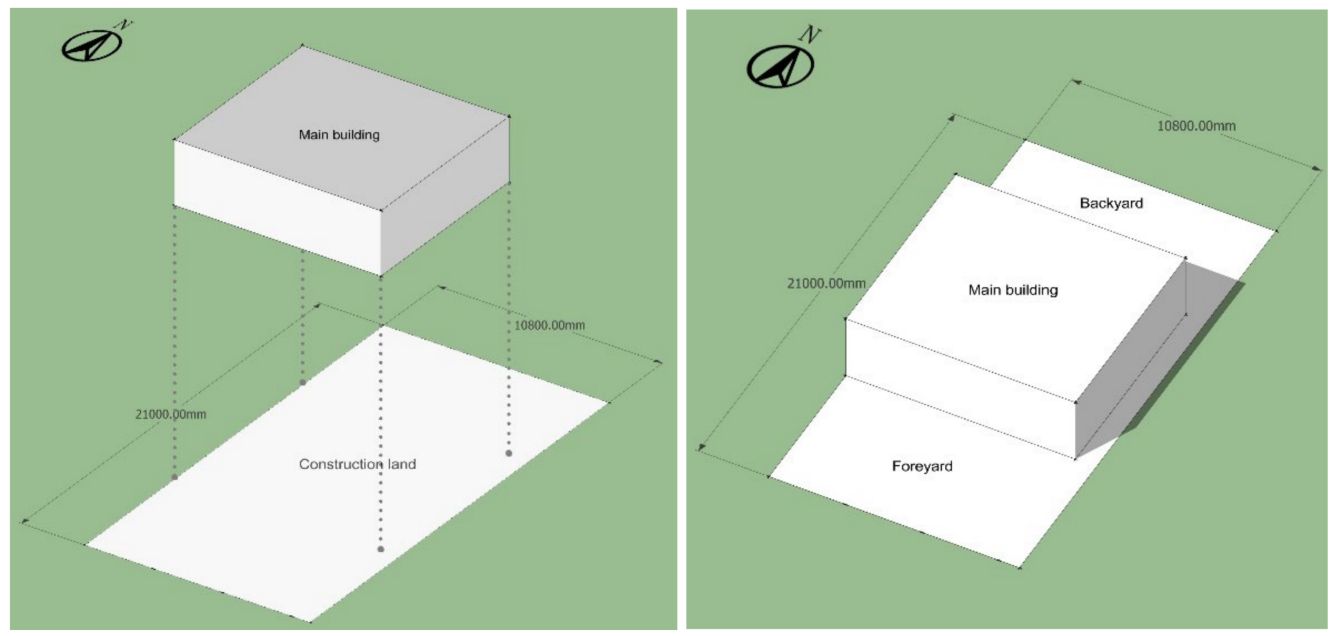

Figure 20. Diagram of vernacular dwelling with foreyard and backyard.

Firstly, a backyard can be used as a buffer to improve insulation in winter, and the main building can maintain a good wind environment for the foreyard. Secondly, it can efficiently divide the courtyard for the requirements of productivity and living. The foreyard is often used for living activities, and the backyard is used for assisting agricultural productivity, which actually prevents the mixed use of yards and can improve the inner environments of both yards. Lastly, with both a foreyard and backyard, there are no connections with outside streets, which can prevent noise problems. Therefore, from the perspective of both space usage or energy saving, the design of both yards in vernacular dwellings is a better choice.

Theoretically, backyards are used for agricultural production; the usage time and frequency are much less than that of foreyards. As long as the production requirements can be met, the backyard should not be too large, and more space should be designed for a foreyard.

\subsubsection{Attics in Vernacular Dwellings}

In contrast to dwellings in urban areas, rural vernacular dwellings need more storage space for agricultural production needs, and attics can be used to keep farming tools and straw; they can also be used to store grains and other crops after harvest. Because gully regions in the Loess Plateau are one of the most drought-prone areas in China, residential buildings in traditional vernacular dwellings often have sloped roofs, which are good for collecting water on rainy and snowy days. Generally, there is a gutter at the edge of the eaves, which is connected with a pipe to collect rainwater into a container on the ground. Therefore, a reasonable roof slop can help collect more rainwater.

Compared with traditional dwellings, the story height is designed to be higher. The initial altitude of the slope roof starts from the ceiling of main building; the height is around $3.6 \mathrm{~m}$, and most of the ridge is about $5 \mathrm{~m}$. These attic spaces can be used for storing and preventing the cold wind entering the foreyard in winter, and can act as buffer area for better insulation, as shown in Figure 21. Generally, the space for people entering should be over $2 \mathrm{~m}$, and most of sloped roof height should be about $1.5 \mathrm{~m}$, a little bit lower for people to use. Because of the invariable building height, the initial altitude of sloped roof can be adjusted from $3.6 \mathrm{~m}$ to $3 \mathrm{~m}$. There is no influence on space usage of the main building, which makes attics with a height over $2 \mathrm{~m}$ much more accessible. 

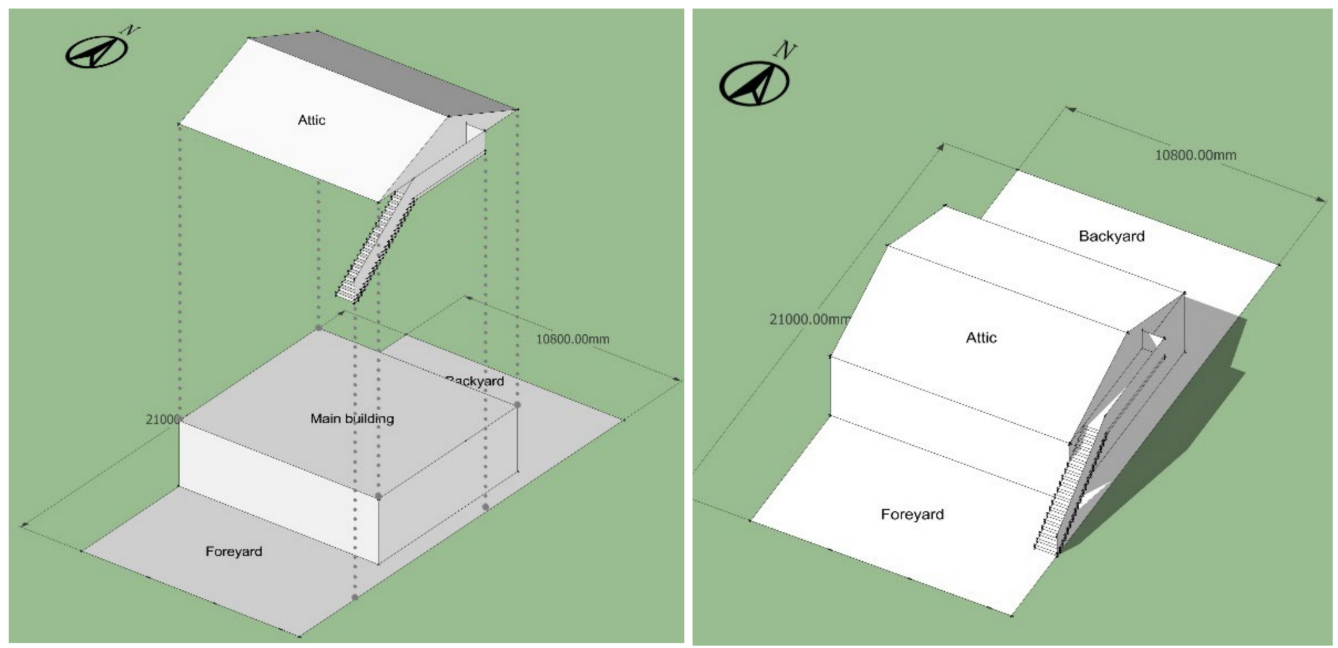

Figure 21. Diagram of vernacular dwellings with attic.

\subsubsection{Kitchen and Bathroom in Vernacular Dwellings}

As important subsidiary rooms, the kitchen and bathroom play an important role in daily life. The traditional cooking method in gully regions is to use firewood as the main fuel; usually, there is a large amount of firewood stored in the kitchen, which takes up a lot of space. Moreover, firewood burning produces a lot of smoke. Generally, the kitchen is designed to be outside of the main building. However, if the distance between the kitchen and main building is too large, residents need to walk to the outside from the main building to the kitchen, which is inconvenience for use. In order to meet residents' requirements for a modern and convenient life, the kitchen should be designed and planned according to the local reality and modern cooking methods.

According to the field investigation and a large amount of interviews with local residents, most of the residents still keep a traditional stove for cooking, usually combined with electricity and gas. Therefore, the kitchen should be designed to be at the south side of the main building and connect with the main building. In this way, the kitchen can be relatively independent, and the influence caused by smoke will be less. Moreover, residents do not need to pass by the outside space to enter the kitchen, and the heat from cooking can be transferred to the main building by a chimney flue, which could reduce energy consumption in winter. Then, the bathroom can be connected to the kitchen; this arrangement is more intensive, which can reduce the usage of water pipes and electricity lines, and makes the courtyard tidier. Waste water from the bathroom can be used directly to irrigate plants in the foreyard and saves water. Because of the summer monsoon in the gully regions is usually southeast, in order to increase the inner ventilation, the kitchen and bathroom should be designed at the west side of the courtyard, so wind can be better enter the courtyard, and the single sloped roof can prevent the northwest wind entering the courtyard in winter, Figure 22. 


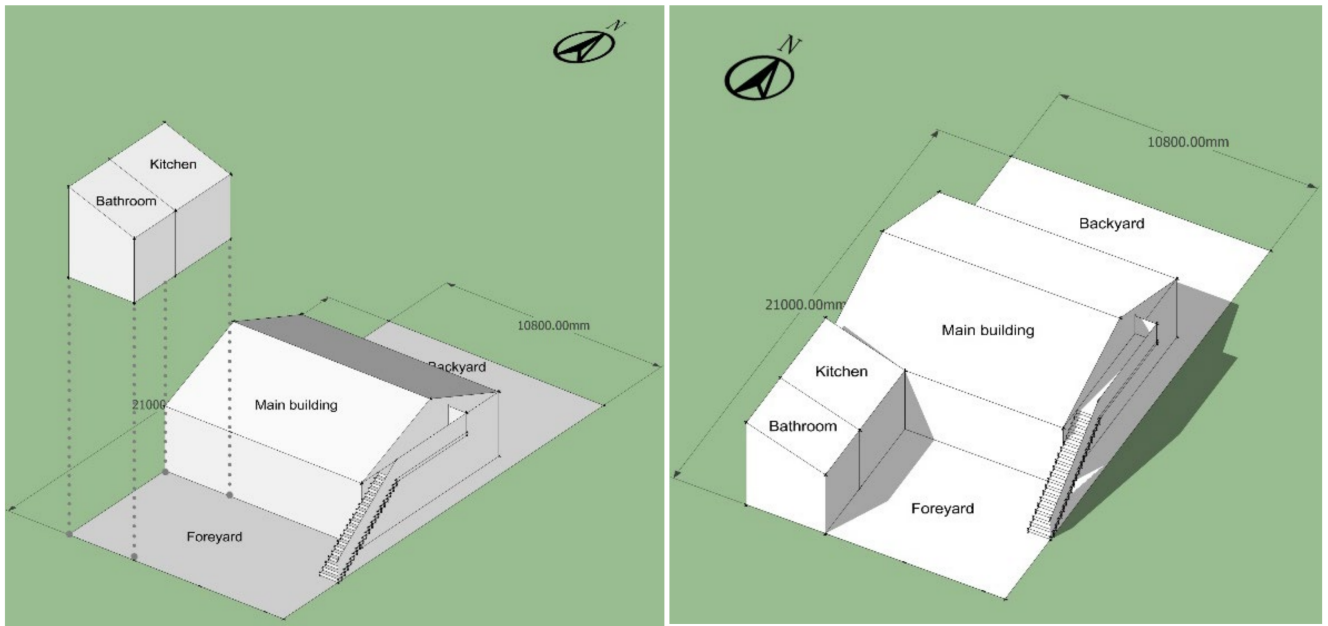

Figure 22. Diagram of a kitchen and bathroom in a vernacular dwelling.

\subsubsection{Toilets in Vernacular Dwellings}

Toilets in the gully regions of the Loess Plateau are usually pit toilets. Residents need to clean these after usage, and feces can be used as an important fertilizer for land. In order to avoid the influence of unpleasant smells, the layout of toilets is very important. According to the local climate, if there is both a foreyard and backyard in the courtyard, the toilet can be designed in the northwest corner of the backyard, Figure 19. In this way, in summer, bad smells cannot be brought into the courtyard by the southeast monsoon, and in winter, the single sloped roof also can prevent the cold northwest wind entering the courtyard, Figure 23.
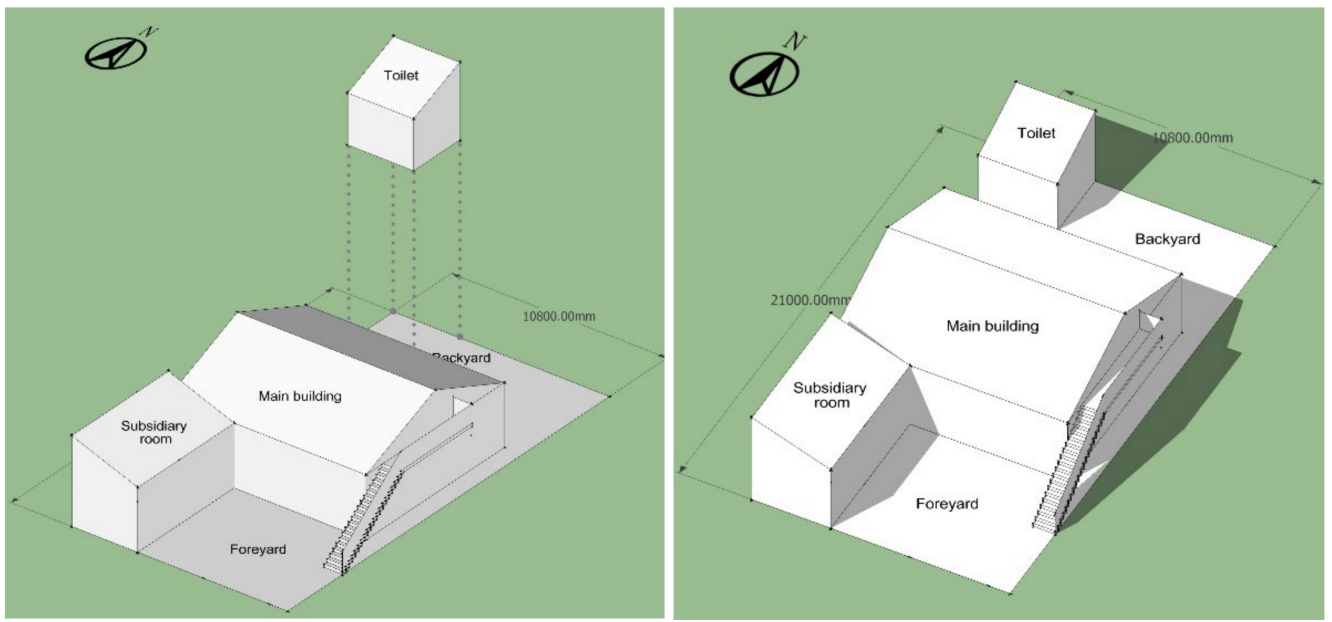

Figure 23. Diagram of a toilet in a vernacular dwelling.

\subsubsection{Sunshade in Vernacular Dwellings}

Sunshade space is an important space for production-related activities in the courtyard of vernacular dwellings in gully regions; the main functions include: storage, piling debris, drying grains, and feeding livestock. In this investigation, it was found that the cost of livestock feeding is much higher than buying meat from market, and feeding livestock also has an impact on the sanitary conditions. At present, there are few residents feeding livestock. Instead of this, residents park their farming vehicles and store farming tools in the sunshade space.

The sunshade space is suggested to be planned in the north part of the backyard, connected to the toilet, as shown in Figure 19. In this way, the backyard can be tidier, and the usage efficiency can be improved. Moreover, the wall can be shared by the sunshade 
space and toilet to prevent the cold northwest wind entering the courtyard, as shown in Figure 24.
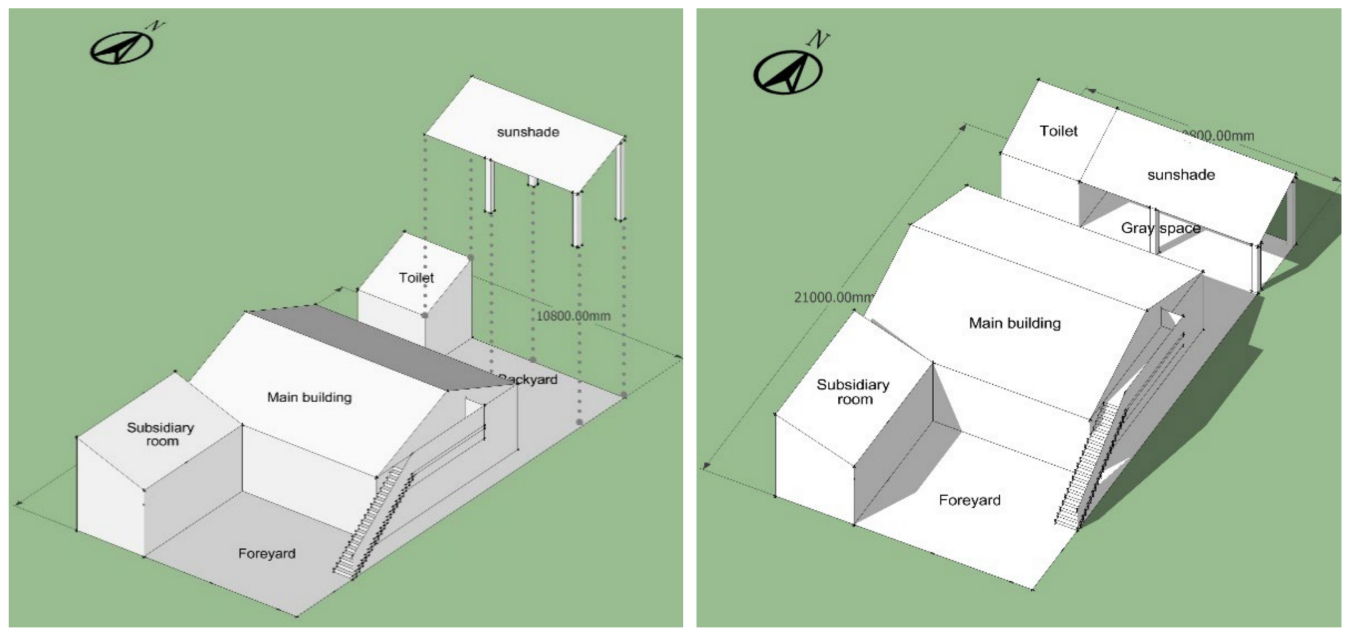

Figure 24. Diagram of a sunshade in a vernacular dwelling.

\subsubsection{Yard Walls in Vernacular Dwelling}

The yard wall is the main enclosure structure in vernacular dwellings. A suitable height can prevent interruption from outside and create a better inner environment. However, if the height is too high, it will give the residents the feeling of enclosure and repression, and this is also not good for light and ventilation. According to the local climate, the south wall should be lower, which is good for the lighting of the environment and ventilation in summer. However, the north wall should be higher to avoid the cold winter wind entering the vernacular dwellings, Figure 25.
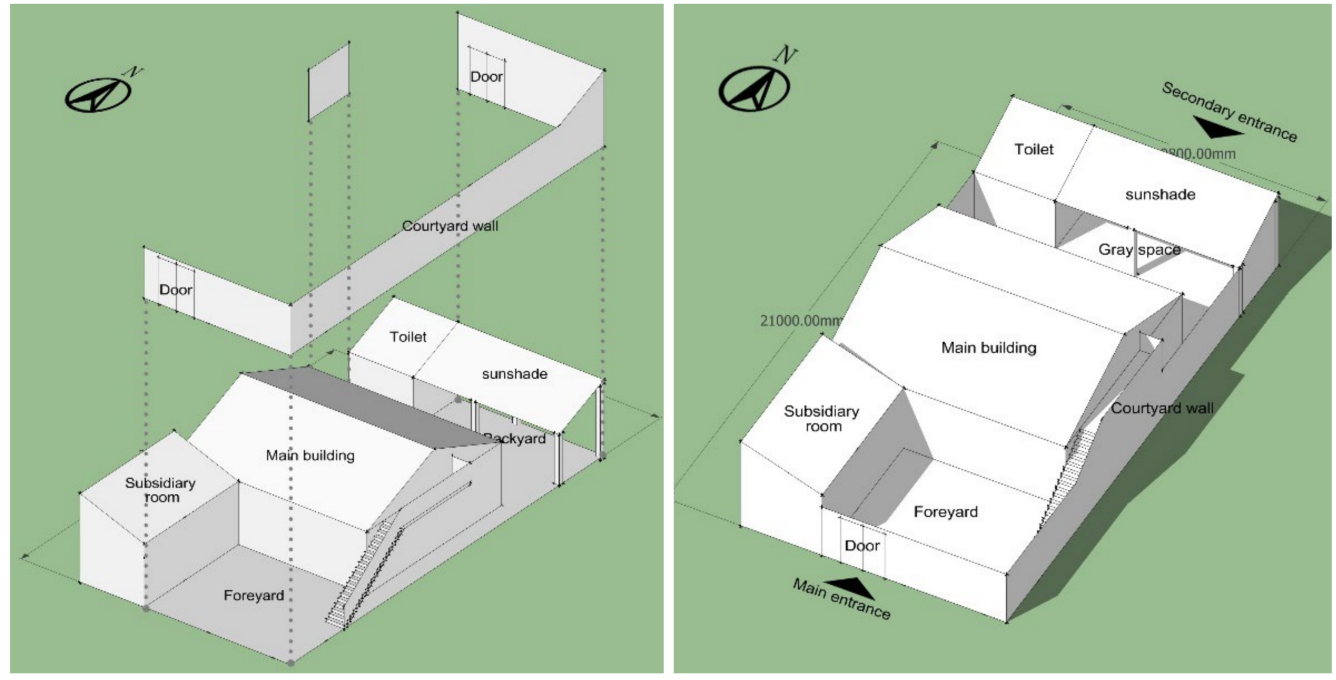

Figure 25. Diagram of a yard wall in a vernacular dwelling.

\subsubsection{Vegetation in Vernacular Dwellings}

Because of the close relationship between the thermal environment, land interface, and dry and rain-shortage climate in the gully region, the design of flexible flooring in the courtyard can improve the temperature and humidity conditions and have an important influence on the thermal environment and villagers' production and living [45]. Flexible flooring means the courtyard floor can be constructed by both hard materials such as concrete, stone, and bricks or soft materials such as plantings. This flexible flooring should be used and combined with the traditional ecological experience, Figure 26. 

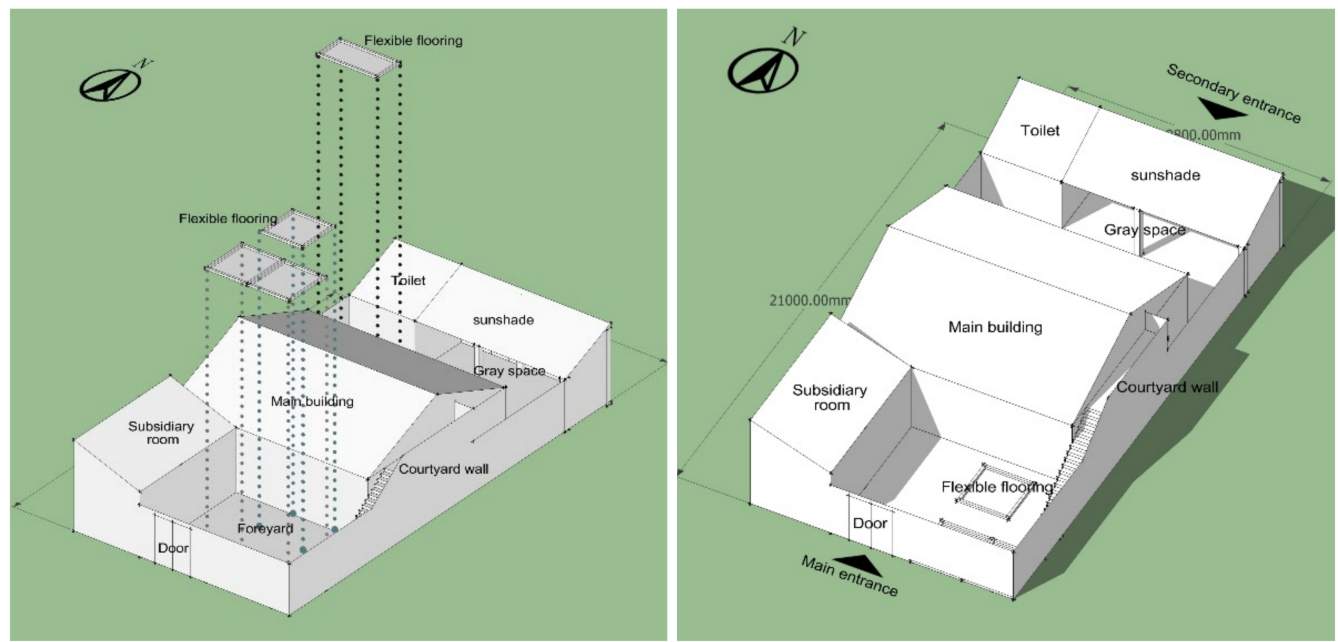

Figure 26. Diagram of flexible flooring in a vernacular dwelling.

(1) Broad-leaf and deciduous fruit trees can be planted, such as persimmon trees and walnut trees; they can be planted in the south area of the foreyard. In summer, these trees flourish; they can hinder the sunshine and adjust the courtyard's climate by evaporating moisture. In winter, all the leaves fall, and sunshine can enter the courtyard making it warmer.

(2) The garden greening and garden planting can be combined. Some vegetables for daily consumption can be planted inside the courtyard, which can be used to increase the humidity due to the vegetables' evaporation in order to stabilize the courtyard's temperature and further adjust its micro-climate; this can also save living costs at the same time.

Moreover, water cellars are very important water storage equipment in the gully region of the Loess Plateau, which can collect and store rainwater for the daily use. Nowadays, modern technology has gradually improved water reuse systems; if the traditional water cellars can be combined with these systems, it would be a good combination of the modern and the traditional.

\subsection{Thermal Environment Verification Simulation}

Base on the previous design for environmental conditions, the thermal environment was simulated. The courtyard area was designed as $21 \mathrm{~m} \times 10.8 \mathrm{~m}$; the height of residential buildings was $5.1 \mathrm{~m}$; the southeast yard wall was $1.8 \mathrm{~m}$; and the northwest wall was $3 \mathrm{~m}$. The analysis results are shown as follows in Table 8.

The results of the simulation showed that: by combining the thermal environment analyses of newly built vernacular dwellings and traditional regional spatial layouts, the thermal environment for tradition-based new vernacular dwellings is relatively good in both summer and winter. The ecological spatial layout of tradition-based new vernacular dwellings corresponds to local living culture and living habits, saves land resources, and supplies better comfort for the thermal environment within the courtyard. 
Table 8. Thermal environment analyses of a tradition-based new vernacular dwelling.

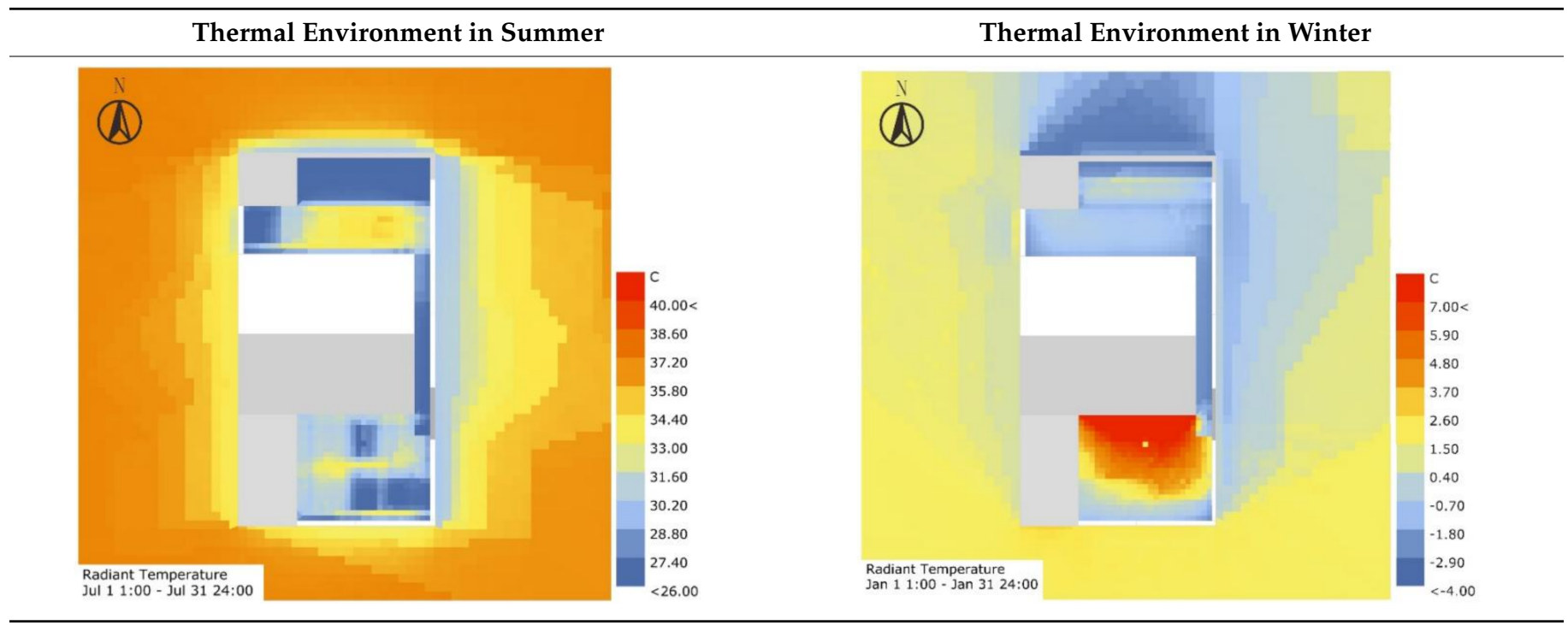

\section{Discussion}

In order to achieve the improvement of the local adaptability and outdoor thermal environment of vernacular dwellings in the gully regions of the Loess Plateau, this research summarized the green architectural design concepts and traditional ecological technologies in traditional vernacular dwellings. Based on a field investigation, the courtyards of current vernacular dwellings were classified into six types on the basis of their different layouts; then, the thermal performance of these six courtyard layouts was simulated using Ladybug and Honeybee. The results clearly indicated the advantages and disadvantages of these different courtyard layouts. With the aim of effectively exploiting their positive attributes for current developments, and based on the literature review and field investigation in typical gully villages, six different courtyard layout dwellings were classified, and their main problems were determined. The first problem was that the regional residential system has been replaced and gradually disappeared. The second is the functional disorder within the courtyard. The last is the poor thermal environment. After the comparative analysis of the advantages and disadvantages of these six different types and their problems, Type $\mathrm{C}$ was determined to have the best thermal environment and traditional spatial layout characteristics. To further improve the thermal comfort of this optimal layout, relative adjustments were made. One is the height adjustment to the yard walls, and another is tree planting. These different adjustments were also analyzed using a thermal simulation. Finally, this paper summarized the design principles for "new" vernacular dwellings, which combine the analysis of outdoor thermal performance and regional adaptability.

\section{Conclusions}

In this paper, the research was mainly focused on the improvement of the outdoor thermal environment based on the research of courtyard layouts. Compared with other relevant research on outdoor thermal environments, this detailed research on courtyard layouts supplies a new view on how to improve the thermal environment within a courtyard. Combining the analysis results of the field investigation, the Ladybug and Honeybee tools software was adopted to simulate the influence of the courtyard's layout on an outdoor microclimate, in which the advantages of function setting were analyzed in detail and description, and the relevant design practice was also systematically analyzed. The simulation results were visual, which made it easier to verify the adjustments made to the traditional vernacular dwellings. Throughout China's history, the culture of being harmonious with nature and customs has been integrated into traditional vernacular dwellings. Traditional ideas about land saving in dwelling design and functional design for daily use, as well as 
the characteristics of traditional vernacular dwellings, should be protected and combined with the current vernacular dwelling construction. This study has emphasized all of these advantages and the importance of ecological design in traditional vernacular dwellings for regional adaptability. Based on regional adaptability and outdoor thermal performance, the proposed "new" traditional vernacular dwelling is evidence that traditional vernacular dwellings have huge value and need to be preserved in new countryside construction.

The new approach proposed in this study was used to evaluate different courtyard layouts of vernacular dwellings and proved to be effective and adequate and may be employed in the research of vernacular dwellings in other regions, but necessary modifications would be strongly recommended due to differences in climate and geographical features. In order to further improve the living comfort and better protect these traditional vernacular dwellings, future research planning is shown as the following:

1. As the indoor space layout could be more impactful for occupants' comfort and wellbeing, in order to fully improve the thermal environment for vernacular dwellings, further research should focus on the inner thermal environment in dwellings. Then, the relationship between the indoor and outdoor thermal environment can be researched as a whole, which will be more reasonable and meaningful. The ecological design and construction of "new" vernacular dwellings can be truly realized through focused research on outdoor thermal environments by the courtyard's layout and indoor thermal environment analyses.

2. In real construction, the ecological layout of "new" vernacular dwellings proposed in this paper should be further analyzed according to its complexity and diversity by various restricted and influencing conditions. In further research, architectural culture and regional architectural technologies contained in traditional vernacular dwellings should also be further explored and applied.

3. Due the limited time and energy, the present study has the limitation that few dwellings were analyzed. A larger-scale investigation is therefore needed. In addition, the conclusions of this paper have not yet been applied in the project design. We hope that the results of this research will stimulate researchers in the field of environment, ecology, urban planning, and other related fields to carry out more research on human settlement planning in the gully region of the Loess Plateau. In addition, to speed up the process of urban and rural integration in this region, we hope that this research will contribute to the Chinese new rural construction.

Author Contributions: Conceptualization, T.Z. and Q.H.; data curation, T.Z. and Q.H.; formal analysis, T.Z.; funding acquisition, D.Z.; investigation, T.Z. and Q.H.; methodology, T.Z., Q.H. and Q.D.; project administration, T.Z. and D.Z.; resources, T.Z., Q.H. and D.Z.; software, T.Z. and Q.D.; supervision, D.Z., W.G. and H.F.; writing—original draft, T.Z. and Q.H.; writing—review and editing, T.Z. and Q.H. All authors have read and agreed to the published version of the manuscript.

Funding: This work was supported by the National R\&D Infrastructure and Facility Development Program of China, grant number 2007DKA32300-12, and the Science and Technology Research and Development Project of Shaanxi Province, grant number 2010K01-123.

Institutional Review Board Statement: Not applicable.

Informed Consent Statement: Not applicable.

Data Availability Statement: Not applicable.

Conflicts of Interest: The authors declare no conflict of interest.

\section{References}

1. Zhang, T.Z. Outline of Loess Plateau; Chinese Environmental and Scientific Press: Beijing, China, 1993.

2. Yu, H.X. A Study of Ecologic Theory and Plan-Designing Methods for Human Habitat in Gully Region on Loess Plateau. Ph.D. Thesis, Xi'an University of Architecture and Technology, Xi'an, China, 22 September 2007.

3. Cao, X.M.; Zhou, R.Q. The spatial features and leading measures of village system in small watershed in loess plateau gully region-A Case Study on Chunhua County, Shaanxi Province. Hum. Geogr. 2008, 5, 53-56. 
4. MOHURD. Thermal Design Code for Civil Building (GB 50176-2016); China Architecture \& Building Press: Beijing, China, 2016.

5. Bureau, China Meteorological. Climate Information Center; Climate Data Office, Tsinghua University, China Standard Weather Data for Analysing Building Thermal Conditions, China Building Industry Publishing House: Beijing, China, 2005.

6. Helena, C. Bioclimatism in vernacular architecture. Renew. Sustain. Energy Rev. 1998, 1, 67-87.

7. Nguyen, A.-T.; Tran, Q.-B.; Tran, D.-Q.; Reiter, S. An investigation on climate responsive design strategies of vernacular housing in Vietnam. Build. Environ. 2011, 46, 2088-2106. [CrossRef]

8. Huang, M.H.; Wang, T.; Zhu, Y.N. Optimization of Urban Spatial Form Of Small Towns In Gullied Loess Plateau. Planners 2016, 3, 114-119.

9. Zhou, Q.H.; Bai, Y.; Yang, Y.L. An exploration on urban space development routes in the loess plateau in the background of new urbanization: A case study on Wohu ravine new district of Mi Zhi county. City Plan. Rev. 2014, 11, 72-78.

10. Yinwu, H. When architects meet craftsmen. J. Archit. 2014, 3, 21-22.

11. Yan, L.; Chunru, L.; Jianwei, Y. Wind direction and speed outside the green architecture, Architectural technology. Archit. Technol. 2013, 5, 15-16.

12. Lai, D.; Guo, D.; Hou, Y.; Lin, C.; Chen, Q. Studies of outdoor thermal comfort in northern China. Build. Environ. 2014, 77, 110-118. [CrossRef]

13. Yoshino, H.; Hasegawa, K.; Matsumoto, S. Passive cooling effect of traditional Japanese building's features. Manag. Environ. Qual. Int. J. 2007, 18, 578-590. [CrossRef]

14. Manioğlu, G.; Yılmaz, Z. Energy efficient design strategies in the hot dry area of Turkey. Build. Environ. 2008, 43, 1301-1309. [CrossRef]

15. Martín, S.; Mazarrón, F.R.; Cañas, I. Study of thermal environment inside rural houses of Navapalos (Spain): The advantages of reuse buildings of high thermal inertia. Constr. Build. Mater. 2010, 24, 666-676. [CrossRef]

16. Xu, X.; Luo, F.; Wang, W.; Hong, T.; Fu, X. Performance-based evaluation of courtyard design in China's cold-winter hot-summer climate regions. Sustainability 2018, 10, 3950. [CrossRef]

17. Zamani, Z.; Heidari, S.; Hanachi, P. Reviewing the thermal and microclimatic function of courtyards. Renew. Sustain. Energy Rev. 2018, 93, 580-595. [CrossRef]

18. Michael, A.; Demosthenous, D.; Philokyprou, M. Natural ventilation for cooling in mediterranean climate: A case study in vernacular architecture of Cyprus. Energy Build. 2017, 144, 333-345. [CrossRef]

19. Hao, S.; Yu, C.; Xu, Y.; Song, Y. The effects of courtyards on the thermal performance of a vernacular house in a hot-summer and cold-winter climate. Energies 2019, 12, 1042. [CrossRef]

20. Xu, C.; Li, S.; Zhang, X.S.; Shao, S. Thermal comfort and thermal adaptive behaviours in traditional dwellings: A case study in Nanjing, China. Build. Environ. 2018, 142, 153-170. [CrossRef]

21. Dhaka, S.; Mathur, J.; Brager, G.; Honnekeri, A.N. Assessment of thermal environmental conditions and quantification of thermal adaptation in naturally ventilated buildings in composite climate of India. Build. Environ. 2015, 86, 17-28. [CrossRef]

22. Huangpu, D.-W. Green Ecological Residence. In Shanxi Architecture 31.14; CNKI: Beijing, China, 2005; pp. 18-19.

23. Fathy, H. Architecture for the Poor: An Experiment in Rural Egypt; University of Chicago Press: Chicago, IL, USA, 2010.

24. Wang, Y.; Zhao, Q.; He, M.; Yang, L. The study on indoor environment of old and new Yaodong dwellings. J. Xi'an Univ. Archit. Technol. 2001, 4, 309-312.

25. Zhang, Y.F.; Liu, Y.; Yao, J.L. Energy-saving Issue in New Rural Construction: Taking Farmhouses in Model Village of Rural Construction in Jingbian Country in the North of Shaanxi Province as an Example. Huazhong Archit. 2009, 1, 107-110.

26. Liu, J.; Wang, L.; Yoshino, Y.; Liu, L. The thermal mechanism of warm in winter and cool in summer in China traditional vernacular dwellings. Build. Environ. 2011, 46, 1709-1715. [CrossRef]

27. Zhu, X.; Liu, J.; Yang, L.; Hu, R. Energy performance of a new Yaodong dwelling, in the Loess Plateau of China. Energy Build. 2014, 70, 159-166. [CrossRef]

28. Liu, J.; Liu, J.; He, Q. Discussion on Design of New Rural Ecological Residences in Ningxia Region-Taking Jianfuqiao Village in Yinchuan as an Example. Build. Sci. 2010, 12, 109-113.

29. Zhou, R.Q. Green Building System and Basic Settlement Pattern of Loess Plateau; China Architecture \& Building Press: Beijing, China, 2007; pp. 184-207.

30. Sun, N. Analysis of Thermal Environment and Energy Saving Technology for Residential Housing in Villages and Towns in Northern Shaanxi; Xi'an University of Architecture and Technology: Xi'an, China, 2012.

31. Yang, L.; Yang, X.; Yan, H. Study on indoor thermal comfort of rural residential houses in winter in Guanzhong Shaanxi. J. Xi'an Univ. Archit. Technol. 2011, 43, 551-556.

32. Zhao, W.; An, Y.; Liu, J. Analysis of winter indoor thermal environment of new residential houses in Guanzhong areas, Shaanxi. Build. Sci. 2013, 29, 72-76.

33. Xu, X. Research on Traditional Vernacular Dwellings in the North. of Wei River of Loess Plateau; Xi'an University of Architecture and Technology: Xi'an, China, 2007.

34. Shui, F. Environments of Power, A Study of Chinese Architecture; Wiley: Hoboken, NJ, USA, 1995.

35. Soflaei, F.; Shokouhian, M.; Zhu, W. Socio-environmental sustainability in traditional courtyard houses of Iran and China. Renew. Sustain. Energy Rev. 2017, 69, 1147-1169. [CrossRef] 
36. Zhao, X.; Hu, H.; Liu, J. Evaluation on environmental suitability of traditional vernacular dwellings. J. Xi'an Univ. Sci. Technol. 2006, 3, 335-337.

37. Xiangbo, W.; Yunxia, W. Developing with Inheriting-Attempt of Modernization in Traditional Folk House in Guanzhong Zone. Huazhong Archit. 2007, 5, 108-110.

38. Liang, R.; Zhang, Q.; Liu, J.P. Strategy research on the ecological design of vernacular dwellings in the Chinese west northern areas under the restrain of local conditions. J. Xi'an Univ. Archit. Technol. 2010, 42, 585-587.

39. Roudsari, M.S.; Pak, M.; Smith, A. Ladybug: A Parametric Environmental Plugin for Grasshopper to Help Designers Create An Environmentally-Conscious Design. In Proceedings of the 13th international IBPSA Conference, Lyon, France, 25-30 August 2013; pp. 3128-3135.

40. Fabbri, K.; di Nunzio, A.; Gaspari, J.; Antonini, E.; Boeri, A. Outdoor Comfort: The ENVI-BUG tool to evaluate PMV values Output Comfort point by point. Energy Procedia 2017, 111, 510-519. [CrossRef]

41. Kensek, K. Visual programming for building information modeling: Energy and shading analysis case studies. J. Green Build. 2015, 10, 28-43. [CrossRef]

42. Evola, G.; Magrì, C.; Margani, G. Modelling Outdoor Thermal Comfort and Energy Demand in Urban. Canyons: Validation of a Novel Comprehensive Parametric Workflow; International Building Performance Simulation Association: Rome, Italy, 2019.

43. Naboni, E.; Milella, A.; Vadalà, R.; Fiorito, F. On the localised climate change mitigation potential of building facades. Energy Build. 2020, 224, 110284. [CrossRef]

44. Calcerano, F.; Martinelli, L. Numerical optimisation through dynamic simulation of the position of trees around a stand-alone building to reduce cooling energy consumption. Energy Build. 2016, 112, 234-243. [CrossRef]

45. GB/T 50378-2014, Assessment Standard for Green Building; Ministry of Housing and Urban-Rural Development of the People's Republic of China: Beijing, China, 2014.

46. Chen, F. Architectural Wind Environment; China Architecture and Building Press: Beijing, China, 2009.

47. Tablada, A.; Blocken, B.; Carmeliet, J.; Troyer, F.D. The Influence of Courtyard Geometry on Air Flow and Thermal Comfort: CFD and Thermal Comfort Simulations. In Proceedings of the 22nd Conference on Passive and Low Energy Architecture, Beirut, Lebanon, 13-16 November 2005; Volume 1, pp. 75-80.

48. Li, J. Ecological Design Experience and Application in the Traditional Vernacular Dwellings; Tian Jin University: Tianjin, China, 2008. 